\title{
Anti-Inflammatory Effects of Resveratrol: Mechanistic Insights
}

\author{
Diego de Sá Coutinho ${ }^{1}$, Maria Talita Pacheco ${ }^{1}$, Rudimar Luiz Frozza ${ }^{2, *}$ \\ and Andressa Bernardi ${ }^{1, *}$ \\ 1 Laboratory of Inflammation, Oswaldo Cruz Institute, Oswaldo Cruz Foundation (FIOCRUZ), \\ Rio de Janeiro 21040-360, Brazil; diego_dsc_@hotmail.com (D.d.S.C.); talipacheco@gmail.com (M.T.P.) \\ 2 Laboratory on Thymus Research, Oswaldo Cruz Institute, Oswaldo Cruz Foundation (FIOCRUZ), \\ Rio de Janeiro 21040-360, Brazil \\ * Correspondence: rudimar.frozza@ioc.fiocruz.br (R.L.F.); andressa.bernardi@ioc.fiocruz.br (A.B.); \\ Tel.: +55-21-2562-1334 (A.B.)
}

Received: 15 May 2018; Accepted: 12 June 2018; Published: 20 June 2018

\begin{abstract}
Inflammation is the principal response invoked by the body to address injuries. Despite inflammation constituting a crucial component of tissue repair, it is well known that unchecked or chronic inflammation becomes deleterious, leading to progressive tissue damage. Studies over the past years focused on foods rich in polyphenols with anti-inflammatory and immunomodulatory properties, since inflammation was recognized to play a central role in several diseases. In this review, we discuss the beneficial effects of resveratrol, the most widely investigated polyphenol, on cancer and neurodegenerative, respiratory, metabolic, and cardiovascular diseases. We highlight how resveratrol, despite its unfavorable pharmacokinetics, can modulate the inflammatory pathways underlying those diseases, and we identify future opportunities for the evaluation of its clinical feasibility.
\end{abstract}

Keywords: resveratrol; inflammation; chronic diseases

\section{Introduction}

Inflammation is a natural protective response of the body to infection or injury; this response helps to maintain tissue homeostasis under stressful conditions [1]. This complex, tightly regulated process serves as a rapid defense mechanism to contain potential pathogens, limit further tissue damage, and stimulate repair mechanisms; consequently, inflammation is crucial for human health [2]. Although inflammatory response processes depend on the precise nature of the initial stimulus and its location in the body, they all share a common mechanism, which consists of the following steps: (1) cell-surface pattern receptors recognize detrimental stimuli; (2) inflammatory pathways are activated; (3) inflammatory markers are released; (4) inflammatory cells are recruited; and (5) the target tissues are affected $[3,4]$. This complex set of events results in the cardinal signs of inflammation: pain, heat, redness, swelling, and eventual loss of function [5].

Inflammation can be acute and chronic [1]. Usually, the acute phase is initiated by tissue-resident cells that detect pathogens or trauma, and then send chemical signals which amplify the local response and recruit other cells [2]. Typically, the molecular and cellular events during acute inflammatory responses are efficient, leading to the restoration of tissue homeostasis, and thus, the complete resolution of inflammation [6]. However, altering or prolonging the activation of the inflammatory response, even for low-grade inflammation, can trigger the second stage, called chronic inflammation, which can cause more damage to a host than the pathogen itself [7]. Low-grade inflammation may persist throughout periods of life due to recurrent or persistent infections, and emerging evidence 
indicated that inflammation has a pivotal role in the pathogenesis of several chronic diseases, including metabolic, cardiovascular, pulmonary, and neurological disorders [8-11]. Moreover, studies showed an association between inflammation and some types of cancers [2,12].

Inflammation therapy is based on the use of non-steroidal anti-inflammatory drugs (NSAIDs), which possess multiple side effects and have limited efficacy. These drugs are potent inhibitors of cyclooxygenases 1 and 2 (COX-1 and COX-2). Despite COX-2 being induced by inflammation to trigger the production of pro-inflammatory prostaglandins (PGE2 and PGD2), COX-1 is the constitutive isoform involved in homeostatic processes. Because NSAIDs inhibit both enzyme isoforms, its continuous use can lead to damage to the gastrointestinal tract-the main side effect of these drugs. Therefore, the development of selective COX-2 inhibitors was a strategy in the pipeline for new anti-inflammatory compounds. These selective inhibitors, called coxibs, improved the efficacy of NSAIDs and diminished their damage to the gastrointestinal tract; however, they increased the risk of cardiotoxicity and hepatotoxicity [13]. For this reason, several drugs already approved by the Food and Drug Administration (FDA) were removed from the market. In addition to NSAIDs, glucocorticoids also represent the standard therapy for reducing inflammation. However, resistance to the anti-inflammatory effects of glucocorticoids constitutes a major drawback to the effective control of many diseases. Furthermore, glucocorticoid-associated side effects may involve metabolic disturbances, osteoporosis, and musculoskeletal, gastrointestinal, cardiovascular, neuropsychiatric, and immunological dysfunction $[14,15]$. Consequently, there is an urgent need to find novel, safe, and efficacious agents for the management of inflammation [1].

Accumulating data strongly suggest that phytochemicals from fruits, vegetables, nuts, and herbs may exert relevant beneficial effects due to their intrinsic antioxidant and anti-inflammatory properties [16]. The hermetic properties of phytochemicals were reported to activate adaptive stress response signaling pathways that increase cellular resistance to injury and disease. Thus, natural products as sources of new anti-inflammatory agents attracted increasing interest in the past decades. Among several naturally occurring bioactive substances, resveratrol (RSV, 3,4',5-trihydroxystilbene), one of the most studied phytochemicals, entered the spotlight since the first scientific paper described its possible preventive effect on cancer in mice [17].

RSV is produced by plants as a phytoalexin in response to a stressful stimulus, or to a microbial or fungal infection, providing the plant resistance [18]. First isolated from Veratrum grandiflorum by Takaoka in the 1940s [19], RSV is found in food sources such as fruits, vegetables, and chocolate, and is better known as a constituent of grapes and wines, although it is present in only minimal quantities $[18,20]$. Due to its presence in wine, RSV attracted attention in the early 1990s to explain "the French paradox", which suggested that people from France had a lower incidence of cardiovascular disease despite their high intake of saturated fats, presumably as a result of moderate red wine consumption [21].

The application of RSV attracted increasing interest not only from the pharmaceutical industries, but also from companies investing in cosmetics and food additives. Because of its potential as a topical anti-aging compound due to its downregulation of important transcription factors involved in photoaging, RSV gained popularity in dermatology applications as a cosmeceutical to improve skin health [22-24]. In addition, RSV is already widely distributed as an over-the-counter nutraceutical for its supposed beneficial effects on human health [20]. This increased interest in RSV activity resulted in a range of in vitro and animal studies demonstrating its beneficial effects. Several studies demonstrated the prophylactic and therapeutic properties of RSV in various diseases, including various types of cancer [25,26], diabetes [27], and cardiovascular diseases [28], which are linked by their important anti-inflammatory activity [20]. Furthermore, lifespan prolongation in several species was related to the desirable biological actions of RSV [29-31]. As a pharmacological tool, RSV has a broad spectrum of molecular targets, and it is believed that the observed effects result from its simultaneous action on multiple targets (summarized in Table 1). RSV generally modulates enzymes belonging to various 
classes, including kinases, lipoxygenases, cyclooxygenases, and sirtuins [32], and acts as a potent scavenger of free radicals [33].

Given the scientific interest in RSV over the past decade, this review focuses on understanding the anti-inflammatory effects of RSV against metabolic, cardiovascular, respiratory, and neurodegenerative diseases, as well as cancer.

Table 1. Anti-inflammatory effect of Resveratrol in chronic diseases.

\begin{tabular}{|c|c|c|c|c|}
\hline Disease & Model & Concentration/Dose & $\begin{array}{c}\text { Inflammatory } \\
\text { Molecules Affected }\end{array}$ & Ref. \\
\hline \multirow{12}{*}{$\begin{array}{l}\text { Cardiovascular and } \\
\text { Metabolic } \\
\text { Disorders }\end{array}$} & $\begin{array}{l}\text { High-fat diet in AMPK } \\
\text { knockout mice model }\end{array}$ & $400 \mathrm{mg} / \mathrm{kg}$ v.o. & AMPK & [34] \\
\hline & High-fat diet mice model & $30-400 \mathrm{mg} / \mathrm{kg}$ v.o. & $\begin{array}{l}\uparrow \text { PGC- } 1 \alpha \text { expression } \\
\uparrow \text { SIRT1 activation } \\
\uparrow \text { AMPK phosphorylation } \\
\downarrow \text { TLR } 2 / 4, \text { MyD } 88, \text { NF- } \mathrm{B} B \\
\text { and AMPK } \alpha \text { expression }\end{array}$ & {$[35-38]$} \\
\hline & $\begin{array}{l}\text { TNF- } \alpha \text {-stimulated human } \\
\text { coronary arterial } \\
\text { endothelial cells }\end{array}$ & $1-100 \mu \mathrm{M}$ & $\begin{array}{l}\downarrow \text { ICAM-1 } \\
\text { and iNOS expression } \\
\downarrow \text { NF- } \mathrm{kB} \text { activation }\end{array}$ & {$[39,40]$} \\
\hline & $\begin{array}{c}\text { Phenylephrine or } \\
\text { LPS-stimulated } \\
\text { neonatal cardiomyocytes }\end{array}$ & $50 \mu \mathrm{M}$ & SIRT1-dependent & [41] \\
\hline & $\begin{array}{c}\text { Cigarette smoke } \\
\text { extract-stimulated rat } \\
\text { arteries and cultured } \\
\text { coronary arterial endothelial } \\
\text { cells or Cigarette } \\
\text { smoke-exposed rats }\end{array}$ & $\begin{array}{l}10 \mu \mathrm{mol} / \mathrm{L} \text { or } 25 \mathrm{mg} / \mathrm{Kg} \\
\text { in drinking water }\end{array}$ & $\begin{array}{l}\downarrow \text { iNOS, ICAM-1 } \\
\text { and NF- } \mathrm{B} \text { expression } \\
\uparrow \text { SIRT1 }\end{array}$ & [42] \\
\hline & $\begin{array}{l}\text { Postinfarction heart } \\
\text { failure murine model }\end{array}$ & $15 \mathrm{mg} / \mathrm{Kg}$ in drinking water & $\begin{array}{l}\downarrow \mathrm{p} 38-\mathrm{MAPK} \\
\text { and ERK1/2 expression }\end{array}$ & [43] \\
\hline & $\begin{array}{l}\text { Ischemia/reperfusion } \\
\text { murine model }\end{array}$ & $100 \mu \mathrm{mol} / \mathrm{L}$, i.v. & $\begin{array}{l}\downarrow \text { NO and GMPc-dependent } \\
\downarrow \text { NF- } \mathrm{BB} \\
\text { and TLR4 expression }\end{array}$ & {$[44,45]$} \\
\hline & $\begin{array}{l}\text { Cardiomyocytes } \\
\text { anoxia/reoxygenation } \\
\text { injury in vitro model }\end{array}$ & $5-20 \mu \mathrm{M}$ & $\begin{array}{l}\downarrow N F-\kappa B \\
\text { and TLR4 expression }\end{array}$ & [46] \\
\hline & $\begin{array}{l}\text { Cardiovascular disorder in } \\
\text { streptozotocin-induced } \\
\text { diabetic rats model }\end{array}$ & $0.75-80 \mathrm{mg} / \mathrm{Kg}$ i.g. & $\begin{array}{l}\downarrow \text { NF- } \mathrm{kB} \text { level } \\
\downarrow \text { VEGF expression } \\
\downarrow \text { p-p38 expression } \\
\downarrow \text { ERK } 1 / 2 \\
\text { and AT1R expression }\end{array}$ & {$[47,48]$} \\
\hline & $\begin{array}{c}\text { LPS-stimulated } \\
\text { THP-1-derived macrophages }\end{array}$ & $2.5 \mu \mathrm{M}$ & $\begin{array}{l}\uparrow \text { SIRT1 } \\
\text { and AMPK expression }\end{array}$ & [49] \\
\hline & $\begin{array}{c}\text { Atherosclerosis model } \\
\text { induced by } \\
\text { hypercholesterolemia in rats }\end{array}$ & $50 \mathrm{mg} / \mathrm{kg}$ in daily diet & $\begin{array}{l}\downarrow \text { ICAM-1, NF- } \mathrm{BB} \text { and } \\
\text { p38-MAPK expression } \\
\uparrow \text { SIRT1 }\end{array}$ & [50] \\
\hline & $\begin{array}{l}\text { Atherosclerosis model } \\
\text { induced by } \\
\text { hypercholesterolemia in } \\
\text { (apo E)-deficient mice }\end{array}$ & $25 \mathrm{mg} / \mathrm{Kg}$, v.o. & $\downarrow N F-\kappa B$ expression & [51] \\
\hline \multirow{6}{*}{$\begin{array}{l}\text { Respiratory } \\
\text { Diseases }\end{array}$} & $\begin{array}{l}\text { Cigarette smoke stimulated } \\
\text { human lung epithelial cells }\end{array}$ & $10 \mu \mathrm{M}$ & $\uparrow$ Nrf2 expression & [52] \\
\hline & $\begin{array}{c}\text { Non-stimulated } \\
\text { human lymphocyte }\end{array}$ & $12.5 \mu \mathrm{mol} / \mathrm{L}$ & $\downarrow N F-\kappa B$ expression & [53] \\
\hline & $\begin{array}{c}\text { Cigarette smoke exposure } \\
\text { + LPS rats model }\end{array}$ & $50 \mathrm{mg} / \mathrm{kg}$ v.o. & $\begin{array}{l}\uparrow \text { SIRT1 } \\
\text { and PGC- } 1 \alpha \text { expression }\end{array}$ & [54] \\
\hline & $\begin{array}{c}\text { Cigarette smoke exposure } \\
\text { mice model }\end{array}$ & $1-3 \mathrm{mg} / \mathrm{kg}$ v.o. & $\begin{array}{l}\downarrow N F-\kappa B \\
\text { nuclear translocation }\end{array}$ & [55] \\
\hline & $\begin{array}{l}\text { OVA-induced mice } \\
\text { asthma model }\end{array}$ & $10-50 \mathrm{mg} / \mathrm{kg}$ v.o. & $\begin{array}{l}\uparrow \text { NPP4A expression } \\
\downarrow \text { Akt phosphorylation } \\
\downarrow \text { TGF- } \beta 1 / \text { phosphorylated } \\
\text { Smad } 2 / 3\end{array}$ & {$[56,57]$} \\
\hline & $\begin{array}{l}\text { OVA-induced mice } \\
\text { asthma model }\end{array}$ & 30 mg/kg i.p. & $\begin{array}{l}\uparrow \text { PTEN expression } \\
\downarrow \text { MUC5AC expression }\end{array}$ & {$[58,59]$} \\
\hline
\end{tabular}


Table 1. Cont.

\begin{tabular}{|c|c|c|c|c|}
\hline Disease & Model & Concentration/Dose & $\begin{array}{c}\text { Inflammatory } \\
\text { Molecules Affected }\end{array}$ & Ref. \\
\hline & $\begin{array}{l}\text { LPS-induced mice } \\
\text { ARDS model }\end{array}$ & 5-30 mg/kg i.p. & $\begin{array}{l}\downarrow \text { NF- } \mathrm{BB} \text { p65 } \\
\text { nuclear translocation } \\
\downarrow \text { p38 MAPK expression }\end{array}$ & {$[60,61]$} \\
\hline \multirow{5}{*}{ Neuroinflammation } & $\begin{array}{l}\text { LPS-induced murine } \\
\text { RAW } 264.7 \text { macrophages } \\
\text { and microglial BV-2 cells }\end{array}$ & $25-100 \mu \mathrm{M}$ & $\begin{array}{l}\downarrow \text { TLR } 4 \text { oligomerization } \\
\downarrow \text { NF- } \kappa \text { B activation } \\
\downarrow \text { I } \mathrm{B} \text { kinase } \\
\text { and I } \kappa \text { B phosphorylation } \\
\downarrow \text { STAT1/3 signaling }\end{array}$ & [62] \\
\hline & $\begin{array}{l}\text { LPS- stimulated mouse } \\
\text { microglia BV2 cells }\end{array}$ & $5-50 \mu \mathrm{M}$ & $\begin{array}{l}\uparrow \text { PGC- } 1 \alpha \text { expression } \\
\downarrow \text { NF- } \mathrm{kB} \text { p65 translocation }\end{array}$ & [63] \\
\hline & $\begin{array}{c}\text { Neurotoxin MPTP- } \\
\text { stimulated dopaminergic } \\
\text { SN4741 cells }\end{array}$ & $5-10 \mu \mathrm{M}$ & $\uparrow$ PGC- $1 \alpha$ expression & [64] \\
\hline & $\begin{array}{c}\text { 6-OHDA induced } \\
\text { Parkinson's rat model }\end{array}$ & $20 \mathrm{mg} / \mathrm{kg}$ v.o. & $\downarrow \mathrm{COX}-2$ & [65] \\
\hline & AD model induced by $A \beta$ & 5-10 $\mu \mathrm{M} 5$ mg/kg i.p. & $\begin{array}{l}\downarrow \text { GFAP } \\
\downarrow \text { JNK and GSK-3 } \beta \\
\text { activation } \\
\downarrow \text { p- } \beta \text {-catenin }\end{array}$ & {$[66,67]$} \\
\hline \multirow{14}{*}{ Cancer } & $\begin{array}{c}\text { TNF- } \alpha \text {-stimulated HepG2 } \\
\text { human hepatocellular } \\
\text { carcinoma cells }\end{array}$ & $10-100 \mu \mathrm{M}$ & $\downarrow$ NF- $\mathrm{kB}$ expression & [68] \\
\hline & $\begin{array}{c}\text { TNF- } \alpha \text {-stimulated U373MG } \\
\text { human glioma cell }\end{array}$ & $5-20 \mu \mathrm{M}$ & $\begin{array}{l}\downarrow N F-\kappa B \text { and uPA } \\
\text { and uPAR expression }\end{array}$ & [69] \\
\hline & $\begin{array}{l}\text { Helicobacter pylori-induced } \\
\text { gastric inflammation in mice }\end{array}$ & 100 mg/kg, v.o. & $\begin{array}{l}\downarrow \mathrm{I} \kappa \mathrm{B} \alpha \text { phosphorylation } \\
\text { and iNOS expression } \\
\uparrow \text { Nrf2 expression }\end{array}$ & [70] \\
\hline & $\begin{array}{c}\text { 3D aggregates of SKOV-3 } \\
\text { and OVCAR-5 ovarian } \\
\text { cancer cell }\end{array}$ & $10-30 \mu \mathrm{M}$ & $\downarrow$ NF- $\kappa B$ expression & [71] \\
\hline & $\begin{array}{l}\text { HEK293T human embryonic } \\
\text { kidney cells transfected with } \\
\text { NF-B Luc vector }\end{array}$ & $10-40 \mu \mathrm{g} / \mathrm{mL}$ & $\begin{array}{l}\downarrow N F-\kappa B \text { activity } \\
\text { and IKK-mediated } \\
\text { NF- } \kappa B \text { activation }\end{array}$ & [72] \\
\hline & $\begin{array}{l}\text { LPS-stimulated Caco-2 and } \\
\text { SW480 human colon } \\
\text { cancer cells }\end{array}$ & $10-50 \mu \mathrm{M}$ & $\begin{array}{l}\downarrow \text { I } \mathrm{B} \alpha \alpha \text { phosphorylation } \\
\downarrow \text { iNOS expression } \\
\text { and TLR4 expression }\end{array}$ & [73] \\
\hline & $\begin{array}{l}\text { HT-29 and SW } 480 \text { human } \\
\text { colon cancer cell lines }\end{array}$ & $100-150 \mu \mathrm{M}$ & $\begin{array}{l}\downarrow \text { IGF-1R/Akt } \\
\text { and Wnt/ } \beta \text {-catenin } \\
\text { signaling pathway } \\
\uparrow \text { p53 protein }\end{array}$ & [74] \\
\hline & $\begin{array}{l}\text { Human bladder cancer cell } \\
\text { line T2 } 2 \text { or xenograft cancer } \\
\text { model in mice }\end{array}$ & $50-200 \mu \mathrm{M}$ or $20 \mathrm{mg} / \mathrm{Kg}$, i.p. & $\downarrow$ Akt expression & [75] \\
\hline & $\begin{array}{c}\text { HepG2 Human } \\
\text { hepatocellular carcinoma } \\
\text { and Chang liver cells }\end{array}$ & $200 \mu \mathrm{M}$ & $\begin{array}{l}\downarrow \text { p38 MAP kinase } \\
\text { and PI3K/Akt expression }\end{array}$ & [76] \\
\hline & $\begin{array}{l}\text { Glioblastoma-initiating cells } \\
\text { or xenograft cancer model } \\
\text { in mice }\end{array}$ & 5-20 $\mu \mathrm{M}$ or $10 \mathrm{mg} / \mathrm{Kg}$, i.p. & $\begin{array}{l}\downarrow \mathrm{PI} 3 \mathrm{~K} / \mathrm{Akt} \\
\text { and NF- } \mathrm{kB} \text { expression }\end{array}$ & [77] \\
\hline & $\begin{array}{l}\text { RPMI 8226, U266, and KM3 } \\
\text { multiple myeloma cell lines }\end{array}$ & $100-200 \mu \mathrm{M}$ & $\downarrow$ NF- $\kappa B$ expression & [78] \\
\hline & $\begin{array}{l}\text { U266 and RPMI } 8226 \\
\text { multiple myeloma cells }\end{array}$ & $50 \mu \mathrm{M}$ & $\begin{array}{l}\downarrow \text { NF- } \kappa \text { B expression } \\
\downarrow \text { STAT3 activation }\end{array}$ & [79] \\
\hline & $\begin{array}{l}\text { SH-SY5Y human } \\
\text { neuroblastoma cells }\end{array}$ & $50-100 \mu \mathrm{M}$ & $\downarrow$ ERK1/2 phosphorylation & [80] \\
\hline & $\begin{array}{c}\text { HeLa human cervical } \\
\text { squamous carcinoma cells }\end{array}$ & $50 \mu \mathrm{M}$ & $\begin{array}{l}\downarrow \text { JNK, p38, } \\
\text { and ERK2 activities }\end{array}$ & [81] \\
\hline
\end{tabular}

v.o. $=$ via oral; i.v. $=$ intravenous; i.g. $=$ intragastric; i.p. $=$ intraperitoneal; $\uparrow=$ enhances and $\downarrow=$ decreases. 


\section{Resveratrol Metabolism and Bioavailability}

Mounting evidence indicates that RSV has a broad range of desirable biological actions. Despite its therapeutic properties, the application of these beneficial effects remains very limited. RSV exists as two geometric isomers: cis (Z) and trans (E). The trans-isomer is more abundant and biologically active than the cis-isomer. However, it was already demonstrated that RSV is extremely photosensitive, and $80-90 \%$ of the trans-RSV in solution is converted to cis-RSV upon exposure to light for $1 \mathrm{~h}$ [82]. Furthermore, the poor water solubility of RSV is another constraint for its biological application.

Although the oral absorption of RSV by humans is high (approximately 75\%) [83,84], its bioavailability is less than $1 \%$ due to extensive intestinal and liver metabolism, involving glucuronic acid conjugation and sulfation that generate the key metabolites trans-resveratrol-3-O-glucuronide and trans-resveratrol-3-sulfate, respectively [83,85-87]. Since this polyphenol is known to have poor bioavailability in that it is rapidly metabolized and excreted, only trace concentrations of free RSV can be found in systemic circulation [83,85]. Therefore, the high concentrations of RSV commonly used for in vitro studies may not be physiologically relevant. Furthermore, the results of these studies are not expected to correlate well with those of in vivo studies, thus leading to disappointing outcomes in human clinical trials. Consequently, the successful clinical application of RSV is a severe challenge for the scientific community. To overcome these challenges, efforts were made to develop adequate drug delivery systems to achieve better clinical efficacy. These strategies include various approaches, such as the development of myriad RSV nanoformulations that can improve these inherent biologic limitations of RSV, increase its solubility, and prevent its degradation while preserving its biological activity [88-92].

\section{Anti-Inflammatory Effects of Resveratrol on Metabolic Derangements and Cardiovascular Diseases}

Metabolic disorders, such as obesity and type 2 diabetes, currently reach epidemic proportions, primarily due to a lifestyle based on calorie-rich diets and a lack of physical activity [93]. The incidence of obesity worldwide increased drastically during recent decades. A large part of this risk is due to obesity being a primary factor in the development of insulin resistance, type 2 diabetes, and metabolic syndrome, all of which create an increased risk of cardiovascular disease [94]. Furthermore, obesity is associated with an array of additional health problems, including increased risks of fatty liver disease; dyslipidemia, characterized by high plasma concentrations of triglyceride and low concentrations of high-density lipoprotein cholesterol; atherosclerosis; hypertension; degenerative disorders, including dementia; airway disease; and some cancers [94-97]. These metabolic derangements are all characterized by chronic low-grade inflammation, leading to the development of metabolic syndrome [94-98].

Some studies suggest that the effects of RSV on metabolic syndrome are associated with its ability to mimic caloric restriction, due to increased levels and activity of the protein deacetylase enzyme-silent information regulator 2/sirtuin-1 (SIRT1). SIRT1 plays a central role in the body's response to diet and exercise $[99,100]$. In mice fed a high-calorie diet, several studies showed that long-term treatment with RSV improves factors associated with a longer lifespan, including increased insulin sensitivity [31,34-36], and reduced insulin-like growth factor-1 (IGF-1) levels [31]. RSV treatment also leads to increases in the metabolic rate and mitochondrial number, which might be correlated with increases in peroxisome proliferator-activated receptor- $\gamma$ coactivator $1 \alpha($ PGC $-1 \alpha)$ activity and expression, which control mitochondrial biogenesis in the liver and muscle [31,34]. Additionally, weight loss [34,35,37], reduced fat mass [34], improvements in glucose homeostasis [34,37], and reductions in plasma triglyceride, tumor necrosis factor-alpha (TNF- $\alpha$ ), and monocyte chemoattractant protein-1 (MCP-1) levels [37] were observed. In adipose tissues in mice, TNF- $\alpha$, interferon (IFN)- $\beta$, IFN- $\alpha$, and interleukin (IL)- 6 levels were attenuated, as well as their upstream signaling molecules-toll-like receptors 2 and 4 (TLR2/4), myeloid differentiation primary response 88 (MyD88), and the transcription factor, nuclear factor kappa $\mathrm{B}$ 
(NF- $\mathrm{kB})[37,38]$. These findings were, in part, correlated with increases in AMP-activated protein kinase (AMPK) $[31,34,36,38]$ and SIRT1 activity $[35,38,101]$. In addition, some clinical studies evaluated the effects of RSV in patients with metabolic syndrome, and achieved promising preliminary results, such as weight reduction [102], improved insulin sensitivity [103,104], and glycemic control [104,105]. However, further research should be conducted to confirm the pharmacological potential of RSV for treating the physiological changes of metabolic syndrome.

Although cardiovascular dysfunction might be linked to metabolic syndrome, cardiovascular disorders include any pathological condition of the blood vessels or heart leading to the obstruction of continuous blood supply and nutrients to cardiac tissue, and therefore, to the entire body [106]. Despite being largely preventable, cardiovascular diseases are the most common cause of death worldwide; they are responsible for almost one-third of all global deaths [107]. Furthermore, the number of worldwide deaths related to cardiovascular disorders is expected to reach 23.6 million in 2030 [28]. Inflammation was also established as a central driver of many disorders that affect the cardiovascular system [106]. Accumulating evidence shows that elevated circulating levels of inflammatory markers are associated with an increased risk of future cardiovascular events [108]. However, despite significant advances in cardiovascular research, much work remains to be done to reveal novel targets for therapeutic intervention [106]. Since RSV was linked to "the French Paradox" and shown to play a pivotal role in the protection of the cardiovascular system [28], accumulating evidence showed that its anti-inflammatory activity might underlie its protective mechanism against cardiovascular diseases.

Several in vitro studies revealed the anti-inflammatory effects of RSV in cardiac tissue, as evidenced by the inhibition of intercellular adhesion molecule 1 (ICAM-1), inducible nitric oxide synthase (iNOS), and IL-1 $\beta$ messenger RNA (mRNA) expression in human coronary arterial endothelial cells stimulated by TNF- $\alpha$ and treated with RSV [39]. Notably, it was already demonstrated that RSV inhibits TNF- $\alpha$ - and IL-6-induced increases in monocyte adhesion in primary human coronary arterial endothelial cells, which reduces pro-inflammatory NF- $\mathrm{kB}$ levels [40]. Another study showed that RSV decreases the level of eotaxin-1, a chemokine related to eosinophil recruitment, in human pulmonary artery endothelial cells stimulated with TNF- $\alpha$ or IL-13. This reduction was followed by the inhibition of the expression of the pro-inflammatory transcription factors, Janus kinase 1 (JAK1), phosphorylated extracellular signal-regulated kinase (ERK) 1/2, c-Jun N-terminal kinase (JNK), and signal transducer and activator of transcription (STAT) 6 , and the reduction of the p65 subunit of NF-kB [109]. It is known that treatment with RSV also suppresses the bacterial lipopolysaccharide (LPS)-induced tissue factor expression in human peripheral blood mononuclear cells, which is the major initiator of the extrinsic blood coagulation pathway that is also involved with intracellular inflammation signaling [110]. Moreover, a study by Planavila and colleagues showed that RSV prevents phenylephrine, a hypertrophic agonist, or LPS-induced increases in MCP-1 levels in neonatal cardiomyocytes, suggesting that this effect is due to the activation of SIRT1 [41]. Csiszar et al. already showed the association between the anti-inflammatory effects of RSV and SIRT1 activation. Importantly, the authors showed that cultured coronary arterial endothelial cells stimulated with cigarette smoke extract, but previously treated with RSV, had decreased NF-kB transcriptional activity and iNOS, ICAM-1, IL-6, IL-1 $\beta$, and TNF- $\alpha$ expression. Curiously, these effects were significantly attenuated by SIRT1 knockdown [42].

Cardiovascular diseases can result in heart failure, a progressive cardiac muscle disorder that leads to the deterioration of heart function, and results in the inability to meet the normal metabolic and energy needs of the body [111]. Some studies investigated the anti-inflammatory effects of RSV on heart failure using various animal models. A previous study showed that oral RSV treatment for 28 days significantly attenuated macrophage and mast-cell infiltration in the left ventricles of C57BL6 mice subjected to pressure overload-induced heart failure, induced by transverse aortic constriction surgery [112]. Furthermore, daily RSV intake for eight weeks resulted in cardioprotective effects against advanced-stage heart failure in rats subcutaneously injected with isoproterenol, a strong sympathetic 
agent used to induce myocardial infarction. Interestingly, this protective effect was accompanied by a reduction in pro-inflammatory members of the mitogen-activated protein kinase superfamily (p38-MAPK) and ERK1/2, suggesting that the regulation of these pro-inflammatory pathways may contribute to the beneficial effects of RSV in cardiac disorders [43].

Heart failure can also be attributable to the detrimental effects of acute myocardial ischemia/reperfusion injury [113], and anti-inflammatory effects of RSV on this type of injury were reported. In a recent study, Cong and co-workers showed that reduced myocardial infarction areas and myocardial myeloperoxidase levels, induced by RSV in a model of myocardial ischemia, were accompanied by decreased TNF- $\alpha$ concentrations in the serum and myocardium. Notably, these effects were abolished when the animals were treated with RSV combined with a nitric oxide (NO) synthase inhibitor and with a cyclic guanosine monophosphate (cGMP) inhibitor, indicating that these pathways are important for the anti-inflammatory activity of RSV [44]. Similarly, the authors showed that RSV also reduces the expression levels of NF-KB and TLR4, a known receptor that triggers innate immune responses; these findings further indicate the anti-inflammatory effects of RSV in protecting against myocardial ischemia [45]. These results are in line with previous work showing that RSV protects cardiomyocytes against anoxia/reoxygenation injury via the TLR4/NF- $k B$ signaling pathway [46]. Hypertension is another factor that may drive the development of heart failure. RSV administration for eight weeks significantly reduced serum TNF- $\alpha$ and IL-6 levels in spontaneously hypertensive rats, but this treatment did not improve blood pressure [114]. These results suggest that combining RSV with blood pressure-lowering agents, which commonly do not affect the inflammatory profile, may provide optimal outcomes for reversing cardiovascular complications in hypertensive patients.

As discussed above, metabolic disorders, such as obesity and diabetes, increase the risk of cardiovascular disease development. Patients suffering from both diabetes and cardiovascular disease have a higher risk of mortality than patients without diabetes or heart failure [115]. Recently, a study showed that RSV improved cardiovascular functions in rats injected with streptozotocin, a compound toxic to pancreatic $\beta$ cells. The improvement was linked to decreased serum levels of inflammatory factors, such as TNF- $\alpha$, IL-1 $\beta$, and IL-6, and the inhibition of vascular endothelial growth factor (VEGF), and the suppression of the p38-MAPK and NF-kB pathways [47]. Similarly, 12 weeks of RSV treatment reduced the circulating levels of TNF- $\alpha$, IL-1 $\beta$, and IL-6, and decreased the activation of the inflammatory factors angiotensin type 1 receptor (AT1R), ERK1/2, and p38-MAPK in rat hearts [48]. Furthermore, by treating mice with RSV for two months, Wu and co-workers found reduced serum, heart, and bone marrow-derived monocyte levels of high mobility group box 1 (HMGB-1), a pro-inflammatory cytokine that exerts its effects via binding to receptor for advanced glycation end products (RAGE) and toll-like receptors [116]. In line with these results, Delucchi and collaborators reported decreased HMGB-1 expression in left ventricular myocardial tissue in rats injected with streptozotocin and receiving a low dose of RSV [117].

Atherosclerosis is another coronary heart disease associated mainly with metabolic derangements, and the development of new therapies for this disorder is needed. This chronic disease is associated with arterial inflammation, lipid accumulation in the vessel wall, plaque formation, thrombosis, and late mortal complications, such as myocardial infarction and ischemic stroke [118]. Inflammatory responses play a crucial role in all phases of atherosclerotic development and progression, so the anti-inflammatory activity of RSV could be an interesting alternative for the control of the disease. In cultured THP-1-derived macrophages stimulated with LPS, pretreatment with RSV suppressed the formation of foam cells, which are considered to initiate atherosclerosis; in addition, the MCP-1 concentrations were reduced, and the expressions of SIRT1 and AMPK, a factor that is involved in glucose and lipid metabolism, and inhibits inflammation, were upregulated [49]. In a hyperlipidemia animal model in which rats were fed a cholesterol-enriched diet combined with vitamin D2, RSV treatment decreased the serum levels of IL-1 $\beta$. Additionally, reduced MCP-1, ICAM-1, p65 NF- $\mathrm{kB}$, and p38-MAPK mRNA and protein expression levels were found in the thoracic 
aortas of hypercholesterolemic rats treated with RSV, as well as decreased inflammasome nucleotide binding and domain-like receptor 3 (NLRP3) oligomerization. These effects were followed by the upregulation of SIRT1 mRNA and protein expression [50]. Interestingly, Chang and colleagues previously demonstrated that RSV reduces inflammatory markers, such as aortic macrophage infiltration and NF- $\mathrm{KB}$ expression, in an atherosclerosis model in which apolipoprotein E-deficient mice were fed a high-cholesterol diet [51]. Furthermore, an elegant study conducted by Cabo and co-workers showed that RSV prevented high fat and sucrose diet-induced arterial wall inflammation, and the accompanying increase in aortic pulse wave velocity in nonhuman primates [119]. Although more studies are warranted to understand the mechanisms involved in the anti-inflammatory effects of RSV on metabolic and cardiovascular disorders, the evidence discussed above can provide new options for the development of alternative therapeutic strategies using this polyphenol.

\section{Respiratory Diseases and Resveratrol}

Respiratory diseases are highly prevalent throughout the world, but occur mainly in westernized countries [120]. Despite therapeutic advances, there is a progressive increase in respiratory diseases, which seriously compromises human health [121]. The pathophysiological components and site of the inflammatory response may vary across respiratory diseases; however, the diseases share common characteristics, such as airway space oxidative stress increases, which play an important role in the lesion and inflammatory process [122]. RSV, as mentioned above, is widely known for its antioxidant and anti-inflammatory effects. Growing evidence indicates that RSV plays a protective role in respiratory diseases, which was already demonstrated in preclinical models of important respiratory conditions, such as chronic obstructive pulmonary disease (COPD), allergic inflammation (asthma models), and acute respiratory distress syndrome (ARDS).

COPD is a progressive lung disease with high global morbidity and mortality rates, and is characterized by persistent airflow obstruction and emphysema, which are caused primarily by cigarette smoke inhalation [123]. The mechanisms intrinsic to the pathophysiology of COPD are not yet fully elucidated, but the disease is associated with chronic inflammation that is usually resistant to corticosteroids [124]. In vitro assays using cells from a respiratory system treated with cigarette smoke extract, and cells from COPD patients demonstrated the anti-inflammatory and antioxidant effects of RSV. It was already shown that RSV reduces glutathione (GSH) depletion by augmenting GSH synthesis via activating nuclear factor (erythroid-derived 2)-like 2 (Nrf2), a redox-sensitive transcription factor [52]; RSV also inhibits COPD-related inflammatory mediators, such as IL-6, MCP-1, TNF- $\alpha$, IL-8, and granulocyte-macrophage colony-stimulating factor (GM-CSF), and decreases nuclear NF-kB expression $[53,125,126]$. Cigarette smoke COPD models were used to show that RSV reduces lung histological damage, decreases pro-inflammatory protein levels (IL-6, IL-17, TNF- $\alpha$, and transforming growth factor beta-TGF- $\beta$ ), inhibits airway remodeling, and reduces mucus hypersecretion [127]. RSV further alleviates the inflammation and reconstruction of small airways in the lungs by upregulating SIRT1 and PGC-1 $\alpha$ expression [54]. In line with in vitro data, RSV treatment increases the activity of superoxide dismutase (SOD), GSH peroxidase, and catalase (CAT), as well as preventing the translocation of NF- $\mathrm{KB}$ to the nucleus and its binding activity [55].

Asthma is a heterogeneous clinical syndrome that mainly affects the lower respiratory tract; it is characterized by chronic inflammation, bronchoconstriction, increased airway hyperresponsiveness (AHR), and mucus production [128,129]. Current therapy consists of the combined use of short-acting $\beta 2$ agonists and inhaled corticosteroids, as well as avoiding aggravating environmental factors [128]. In vivo studies over the past few years showed that RSV can effectively control asthma in murine models. RSV has anti-inflammatory effects by suppressing AHR [56,57,130,131], and reducing the infiltration of inflammatory cells, mainly eosinophils, into bronchoalveolar lavage fluid (BALF) [130] and lung tissue [56-58]. Total immunoglobulin E (IgE) and ovalbumin (OVA)-specific IgE levels were diminished in an OVA-induced asthma model, and reductions in IL-4, IL-5 [56,130], TNF- $\alpha$ [132,133], and TGF- $\beta 1$ [57] cytokine levels were found. TGF- $\beta 1$ and 
TGF- $\beta 1 /$ phosphorylated Smad2/3 receptor expression levels in lung tissues were also significantly decreased with RSV treatment $[57,131]$. In addition to the anti-inflammatory effects, using RSV to treat asthma significantly downregulated oxidative stress by decreasing 8-isoprostane levels (an in vivo marker of oxidative stress) [56], reducing reactive oxygen species (ROS) production, and nicotinamide adenine dinucleotide phosphate (NADPH) oxidase cytosolic subunit p47phox expression, and enhancing SOD levels [133] and mitochondrial function [56]. Concerning airway remodeling, RSV attenuated the fibrotic response [132], and reduced sub-epithelial collagen deposition [131] and mucus hypersecretion [130]; RSV reduced mucus hypersecretion via inhibiting Mucin 5AC (Muc5AC), a major component of mucus [59]. The molecular mechanisms underlying the improvement of asthma include the increased lung expression levels of phosphatase and tensin homolog (PTEN) [58] and inositol polyphosphate 4 phosphatase (INPP4A), which are related to reduced protein kinase $\mathrm{B}(\mathrm{PKB} / \mathrm{Akt})$ phosphorylation and activity [56]. It was also reported that RSV inhibits degranulation in mast cells and the protein expression of spleen tyrosine kinase (Syk), which plays an essential role in immune cell activation and lymphocyte development [132].

ARDS is an inflammatory disorder characterized by injury to the vascular endothelium and alveolar epithelium, pulmonary infiltration, and inflammatory mediator production. Various factors, such as pneumonia, sepsis, trauma, smoke, bacteria, and bacterial toxins, can lead to the development of ARDS [134,135]. Despite numerous efforts, there are currently no effective therapies for ARDS. A range of protocols to induce acute lung inflammation were used to demonstrate the beneficial activity of RSV in protecting against lung damage, and reducing inflammation through several possible molecular mechanisms. Similar data showed that RSV treatment improves structural changes in the lungs [60,136-139], decreases pulmonary edema [137-139], improves lung function [137], and diminishes neutrophil infiltration $[134,137,138]$ and myeloperoxidase protein expression and activity in lung tissue [60,61]. Regarding cytokines, RSV significantly modulates IL-1 $\beta[60,139]$, IL-18 [60] IL-6, COX-2 [138], and macrophage inflammatory protein (MIP)-1 $\alpha$ [139] in BALF and systemic TNF- $\alpha$ [61]. Its antioxidant effects are evidenced by reduced oxidative stress, including decreases in the pro-oxidant biomarker malondialdehyde (MDA) and hydrogen peroxide levels, increases in antioxidant biomarkers (GSH, CAT, and SOD activity) $[136,140]$, and the inhibition of iNOS expression, ROS and NO production [60,139], and peroxynitrite formation [136]. These effects of RSV found in the ARDS model are associated with the downregulation of NLRP3 inflammasome activation through blocking NF-kB p65 nuclear translocation and its DNA-binding activity $[60,138,139,141]$. Moreover, the TLR4/Myd88 [138] and p38-MAPK [61,141] pathways are significantly downregulated by RSV.

\section{Effects of Resveratrol on Neuroinflammation}

Despite inflammation triggering complex molecular and cellular responses to neutralize and fight threats so as to restore normal body physiology, excessive or chronic inflammation damages the surrounding healthy tissues [142], and is considered to be actively involved in neurological disorders. For a long time, the brain was considered to be an immune-privileged organ [143]; however, the entire understanding of the interaction between the immune system and the central nervous system (CNS) was revised [144]. The immune system affects the CNS from its borders, and complex immune-CNS crosstalk was shown to play an essential role in protecting and supporting the CNS in health and disease [145,146]. Low-grade inflammation is linked to aging [147], and similar inflammatory processes are thought to occur in the periphery and in the brain, as evidenced by many studies reporting that the induction of systemic inflammation can trigger increased disease pathology in murine models of various CNS disorders [148]. In light of these new findings, immune-CNS interactions and neuroinflammation are recognized as common disease-escalating factors in many CNS pathologies [149]; these diseases include age-related dementia [150], and neurodegenerative diseases of the CNS, such as amyotrophic lateral sclerosis (ALS), Parkinson's disease (PD), Alzheimer's disease (AD), and multiple sclerosis (MS) [151-154]. 
The potential role of polyphenols in aging and neurodegeneration widened with discoveries that they modulate various important cell signaling pathways and sirtuins, a class of proteins involved in longevity and cell survival [29-31]. Given that the activation of inflammatory mechanisms is strongly associated with aging, and may underlie several CNS disorders, an expanding body of preclinical evidence suggests that RSV has the potential to impact a variety of CNS diseases. The hallmark of brain neuroinflammation is the reactive morphology of glial cells, including both astrocytes and microglia [155-157]. Upon activation, microglia secrete a range of pro-inflammatory factors, including prostaglandins, chemokines, cytokines, complement proteins, proteinases, ROS, and reactive nitrogen species, such as NO. The neuroprotective effects of RSV were described in several in vitro and in vivo models of CNS disorders.

RSV was found to reduce LPS-induced NO and TNF- $\alpha$ production in primary microglia [158], prevent LPS-induced microglial BV-2 cell activation [62], inhibit PGE2 and free radical production by rat primary microglia [159], and differentially modulate microglia and astrocyte inflammatory responses [160]. In addition, several studies used the N9 microglial cell line to indicate that RSV attenuated the LPS-induced phosphorylation of p38-MAPK and the degradation of inhibitor of $\mathrm{\kappa B}(\mathrm{I} \kappa \mathrm{B})$, thus reducing the production of NO and TNF- $\alpha[158,161]$. Furthermore, it was shown that RSV can prevent apoptosis in dopamine-producing neurons by inhibiting the production of microglia-derived TNF- $\alpha$ and IL-1 $\beta$ [162], and RSV can suppress IL-6 gene expression and protein secretion in mixed glial cultures under hypoxia/hypoglycemia conditions [163].

Attenuating neuroinflammation is a therapeutic strategy for treating ischemic stroke, and several in vivo studies showed that RSV effectively reduces the increased expression of pro-inflammatory cytokines, inhibits NF- $\mathrm{kB}$, reduces the phosphorylation of p38-MAPK and JNK activation via decreased COX-2 and iNOS expression, and inhibits astroglial and microglial activation induced by ischemia/reperfusion [164-168]. These findings suggest that the suppression of inflammation is associated with the neuroprotective effects of RSV, and RSV could be a promising candidate for stroke treatment.

Once microglia were shown to have functional plasticity and dual pro-inflammatory M1 and anti-inflammatory M2 phenotypes, Yang and collaborators reported that RSV suppressed microglia activation by promoting polarization toward the M2 phenotype via PGC- $1 \alpha$ overexpression [63]. The increased M2 marker expression induced by RSV was accompanied by coactivation of the STAT6 and STAT3 pathways, and linked to the inhibition of NF- $\mathrm{kB}$. The notion that RSV promotes PGC-1 $\alpha$ expression could lead to the application of this polyphenol for PD therapy, as it was already demonstrated that PGC- $1 \alpha$ expression and activation protect dopaminergic neurons in an MPTP mouse model of PD [64]. Interestingly, Jin and collaborators previously found that RSV decreased COX-2 and TNF- $\alpha$ levels in the substantia nigra of rats with 6-hydroxydopamine (6-OHDA)-induced PD [65]; however, thorough studies showing the mechanisms involved in the anti-inflammatory effects of RSV in PD are missing.

Microglial activation and inflammation were pointed out to play a pivotal role in AD pathogenesis. The basis for this assumption comes from studies showing that markers of inflammation such as TNF- $\alpha$, IL-1 $\beta$, IL-6, and other cytokines are increased in the brain, cerebrospinal fluid, and plasma of AD patients [10,169-171]. Mounting evidence suggests neuroinflammation induced by reactive microglia leads to reduced amyloid- $\beta$ peptide $(A \beta)$ clearance, triggers aberrant synaptic pruning $[10,172,173]$, and prompts $A \beta$ and tau pathologies. Taken together, these alterations contribute to impaired synapse function [174] resulting in memory dysfunction, the main characteristic of the disease. Although trials with anti-inflammatory compounds do not yet provide exciting outcomes [175], the lifelong use of NSAIDs was associated with a reduced risk of developing AD [176]. Therefore, polyphenols could provide new options for modulating neuroinflammation in AD.

Studies from our group demonstrated that RSV can protect organotypic hippocampal cultures from A $\beta$-induced toxicity through decreasing TNF- $\alpha$, IL-1 $\beta$, and IL-6 levels, and increasing IL-10 cytokine levels [66]. These salutary effects were highly correlated with the reduction of glial activation 
as a mechanism of protection. Corroborating data appear in a recent study showing that RSV inhibits neuroinflammation triggered by $A \beta$ in cultured astrocytes and microglia [177]. Capiralla and colleagues previously showed that RSV mitigates LPS-induced NF- $\kappa B$ activation by interfering with TLR4 oligomerization, and IKB kinase (IKK) and IKB phosphorylation; these effects potently reduced the transcriptional stimulation of several NF- $\mathrm{KB}$ target genes, including TNF- $\alpha$ and IL-6, in RAW 264.7 macrophages and microglial BV-2 cells [62]. Furthermore, the authors showed that RSV prevented the pro-inflammatory effects of $A \beta$ on macrophages by inhibiting IKB phosphorylation and activation of STAT1 and STAT3, and inhibiting TNF- $\alpha$ and IL-6 secretion. Interestingly, Wight and co-workers reported that RSV inhibited astrocyte production of NO, the cytokines TNF- $\alpha$, IL- $1 \beta$, and IL- 6 , and the chemokine MCP-1, which play critical roles in innate immunity. In addition, the authors also showed that RSV suppressed astrocyte production of IL-12p40 and IL-23, which are known to alter the phenotype of $\mathrm{T}$ cells that are involved in adaptive immunity [178].

TNF- $\alpha$-dependent mechanisms appear to drive memory defects [179], thereby indicating a causal role of inflammation in the deleterious processes linked to AD. Our previous study suggests that the chronic administration of RSV blocked cognitive impairment in an animal model of AD, and this effect seemed to be related to the inhibition of synaptic dysfunction, and microglial and astroglial activation triggered by A $\beta$ [67]. In addition, RSV treatment modulated important cell signaling pathways, such as the JNK, GSK-3 $\beta$, and $\beta$-catenin pathways, which might be involved in neuroinflammation, cell metabolism, and survival. Importantly, the administration of RSV in a mouse model of cerebral amyloid deposition decreased the microglia activation associated with amyloid plaque formation [62,180]. Although a mechanistic link between inhibited microglia activation and the anti-inflammatory effects of RSV was not described in these studies, it is already known that microglial-derived cytokines enhance amyloid precursor protein (APP) processing, induce tau phosphorylation, and contribute to synapse plasticity impairment in neurons [174]. Altogether, these observations are consistent with the idea that RSV can modulate several signaling pathways involved in neuroinflammation.

\section{Anti-Inflammatory Effects of Resveratrol on Cancer}

Advances in diagnostic medicine during the past decades provided highly sensitive tools for early detection of cancer, one of the most commonly diagnosed diseases [181]. Development of cancer is a multistep process involving molecular and cellular alterations conventionally divided into initiation, promotion, and progression $[182,183]$. Together, these processes cause the hallmark of cancer: abnormal cell proliferation that cannot be controlled or stopped. Furthermore, epidemiological, pre-clinical, and clinical studies over the past several decades established a relationship between inflammation and cancer [184]. Inflammation is involved in all of the major steps of cancer initiation, metastasis progression, and drug resistance, and epidemiological studies suggest that as many as $25 \%$ of all cancers may be due to chronic inflammation $[185,186]$. Inflammatory signaling plays decisive roles in the development of cancer, and involves a complex interplay between oncogenic and tumor suppressive transcription factors [187].

Despite scientific breakthroughs during the past decades that expanded our knowledge regarding the cellular and molecular bases of cancer, the development of effective therapies with few side effects remains a challenge; therefore, the prevention of carcinogenesis is an area of considerable interest and research. Natural products may provide one the most promising approaches for reducing cancer via chemoprevention [188]. Given that inflammation is a critical component of tumor progression, and plays a key role in the tumor microenvironment, RSV might be a promising candidate for cancer prevention and/or treatment. RSV activity was documented in various cancer cell types; RSV acts on multiple targets and has anti-inflammatory effects, helping explain the plethora of anticancer pathways synergistically regulated by this polyphenol. After Jang and co-workers found that RSV inhibited carcinogenesis in a mouse skin cancer model in 1997 [17], a growing number of studies placed RSV at the center of anti-cancer research. 
NF- $\mathrm{KB}$ regulates diverse cellular activities related to inflammation, and innate and adaptive immune responses [189], and the deregulation of NF- $\mathrm{KB}$ activity was implicated in the development of cancer [190,191]. Several in vitro, pre-clinical, and clinical studies showed that NF-kB and NF- $\mathrm{KB}$-dependent gene expression play a major role in cancer progression, metastasis, and drug resistance [192]. The anti-inflammatory effects of RSV seem to be related to NF- $\mathrm{KB}$ signaling attenuation [193,194], which drives the inhibition of the growth and invasion of various tumor types [22,68-71,195]. In colorectal cancer cells, for instance, RSV attenuates the phosphorylation, acetylation, and nuclear translocation of NF-KB [72]. Furthermore, RSV was reported to inhibit iNOS expression in colon cancer cells [73]; iNOS is an enzyme induced by cytokines and pro-inflammatory agents. The overproduction of NO can result in cellular injury and inflammation, and plays an important role in colon tumorigenesis. Because the expression and activity of iNOS were demonstrated in human colorectal cancer tissue and animal models [196], the use of RSV as a chemopreventive agent should be investigated. Additionally, it was shown that RSV inhibits the IGF-1R/Akt/Wnt pathways, and activates p53 [74] to impair cell development and tumorigenesis. In line with these findings, Frazzi and co-workers showed that RSV, through modulation of SIRT1, induces increased p53 expression and acetylation, leading to an increase in apoptosis and cell death of a Hodgkin-lymphoma cell line [197]. Therefore, RSV can constitute a promising agent affecting cancer initiation.

Alterations in the Phosphatidylinositol-4,5-bisphosphate 3-kinase (PI3K)/Akt signaling pathway are frequent in human cancer. PI3K/Akt signaling is associated with cell proliferation and survival, and plays a major role in tumor growth, as well as the potential response of a tumor to cancer treatment [198]. Further, PI3K $\gamma$ regulates the chemokine-mediated recruitment and activation of immune cells [199], and Akt regulates the transcriptional activity of NF- $\mathrm{kB}$ by inducing the phosphorylation and subsequent degradation of IKB [200]. Mounting evidence shows that RSV, paradoxically, can inhibit the PI3K/Akt pathway in cancer to regulate cell differentiation, growth, proliferation, and several other activities [75,76,201]. Additionally, it was reported that RSV inhibits the adhesion, invasion, and migration of glioblastoma-initiating cells, both in vitro and in vivo, through suppressing the PI3K/Akt/NF-KB cascade [77]. Given that TNF- $\alpha$ is a strong stimulatory factor in various cancer cell lines [202], previous studies reported that RSV inhibits TNF- $\alpha$-induced cell invasion in many types of cancer cells through inhibiting NF- $\mathrm{kB}[68,195]$. Furthermore, RSV represses the expression of IL-6, B-cell lymphoma 2 (BCL-2), $\mathrm{BCL}-\mathrm{xL}, \mathrm{X}$-linked inhibitor of apoptosis protein, cellular inhibitor of apoptosis protein, VEGF, and matrix metalloproteinase-9 (MMP-9), the syntheses of which are regulated by NF- $\mathrm{KB}[78,203]$. In accordance with these studies, Ryu and colleagues reported that RSV reduces TNF- $\alpha$-induced U373MG human glioma cell invasion through regulating NF- $\mathrm{kB}$ activation [69].

The maintenance of a pro-carcinogenic inflammatory microenvironment linked to multiple alterations in cell signaling pathways was recognized to play a key role in the transitions from a normal cell to a neoplastic malignant cell, as well as during cancer progression. Although our current understanding of these alterations is limited, STAT3 seems to be a critical element in inflammation-related tumorigenesis fostering the proliferation, survival, invasion, and angiogenesis of tumor cells [204]. Additionally, the signaling mediated by STAT3 is interconnected with NF-KB signaling, and the co-regulation of inflammatory and oncogenic genes, such as those coding for IL-1 $\beta$, BCL-xL, Myc, COX-2, and cyclin D1 [204]. Importantly, this interaction can further promote the development of tumors via inducing the expression of pro-tumorigenic genes [79]. It is noteworthy that RSV inhibits proliferation, induces apoptosis, and overcomes chemoresistance through downregulation of STAT3 and NF-KB [79], providing support for its pro-apoptotic and anti-proliferative potential. In line with these observations, it was recently found that RSV could modulate the mitogen-activated protein kinase (MAPK) pathway. Despite needing a constitutively active state of MAPKs for the maintenance of the malignant state, short-term MAPK activation may cause cell apoptosis [205]. At low concentrations, RSV activates ERK1/2; however, at higher concentrations, it can inhibit MAPK [80]. 
In cervical carcinoma cells, RSV inhibits the activation of p38, JNK1, and ERK2 [81]. In contrast, RSV activates ERK1/2 in prostate [206], breast [207,208], glial [209], and ovarian cancer cells [210].

Another outstanding effect of RSV against cancer promotion and progression is related to the control of the expression of microRNAs (miRNAs), mainly those at the crossroads of inflammation, cell differentiation, and homeostasis. For instance, RSV activity appears to be partially dependent on the impaired expression of miR-663, miR-21, and miR-155, which are linked to tumor suppression, oncogenicity, and pro-inflammatory effects, respectively. Modulation of these miRNAs by RSV led to decreased secretion of pro-inflammatory cytokines IL-6, IL-8, and TNF- $\alpha$, reduced expression of adhesion proteins, such as ICAM-1, and leukocyte chemoattractants, and increased production of anti-inflammatory cytokines [211]. Overall, these observations indicate the anti-inflammatory effects of RSV on various types of cancer, and provide new directions for RSV chemoprevention, and its use as a chemotherapeutic agent.

\section{Conclusions}

Extensive research within the past several decades revealed that chronic, low-grade inflammation can underlie the development of several non-communicable diseases, including cancer, and neurodegenerative, respiratory, metabolic, and cardiovascular diseases. Although scientific breakthroughs during the past decades expanded our knowledge of the cellular and molecular mechanisms underlying inflammation, this knowledge is not yet translated into effective therapies. Accumulating data strongly suggest that phytochemicals can interact with multiple targets, and alter the dysregulated inflammatory pathways and mediators, thus indicating the possible development of affordable, novel, and safe drugs for the treatment of inflammatory processes underlying chronic diseases. The growing interest in RSV increased our understanding of how this polyphenol can directly and indirectly modulate major signaling pathways that protect cells from inflammation (Figure 1). While preclinical studies yielded exciting results, there is little clinical evidence that RSV is an effective therapeutic in humans. Although some official systematic clinical trials using RSV treatment in humans had some disappointing outcomes, the difficulties of the clinical application of RSV are enormous, such as its poor water solubility, bioavailability, and dosage. Therefore, in-depth scientific investigations and large-scale clinical trials are required to completely determine the potential of RSV, and provide new options for the better management of inflammation in patients with chronic diseases.

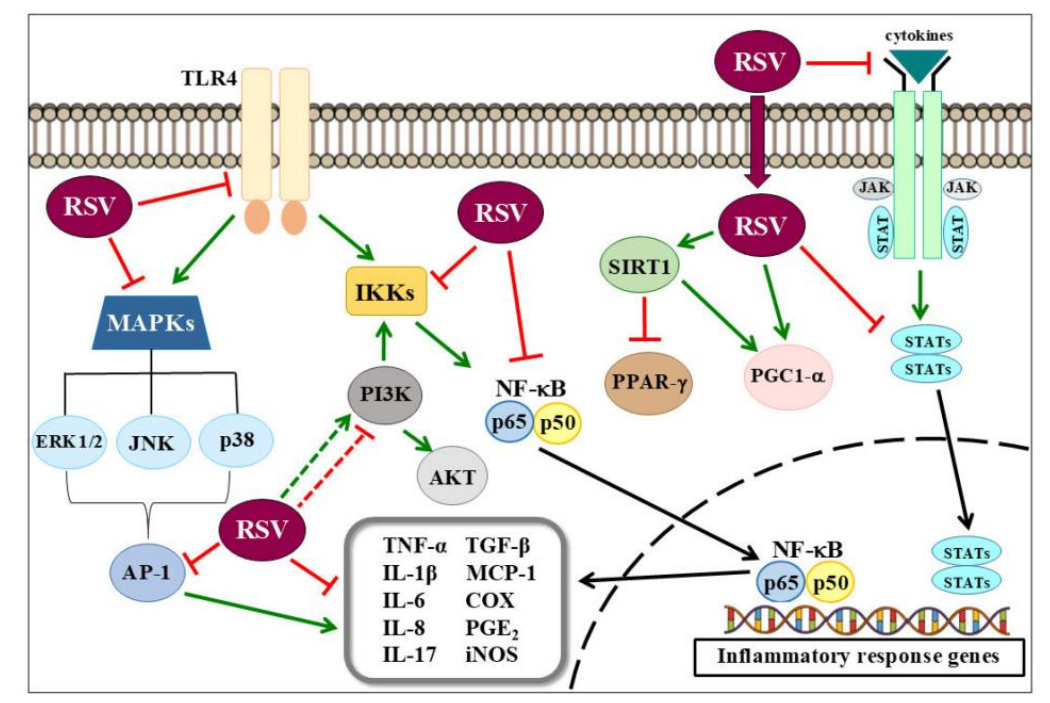

Figure 1. Some of the molecular bases of resveratrol anti-inflammatory effects. Inflammation induces the activation of several cell signaling pathways. The exact mechanism of RSV-mediated protection is not yet understood, but it was described that RSV interacts with multiple targets, and alters dysregulated inflammatory pathways and mediators. Arrows with a point indicate activation, while arrows with a flat tip indicate inhibition. Dashed arrows indicate a poorly understood mechanism. 
Acknowledgments: Work in the authors' laboratories was supported by grants from Conselho Nacional de Desenvolvimento Científico e Tecnológico (CNPq/Brazil), and Fundação Carlos Chagas Filho de Amparo à Pesquisa do Estado do Rio de Janeiro (FAPERJ). D.d.S.C. and M.T.P. were supported by predoctoral fellowships from the Brazil agency CAPES. The authors thank Marco Aurélio Martins (Oswaldo Cruz Foundation) for his critical reading of the manuscript and thoughtful discussions.

Conflicts of Interest: The authors declare no conflict of interest.

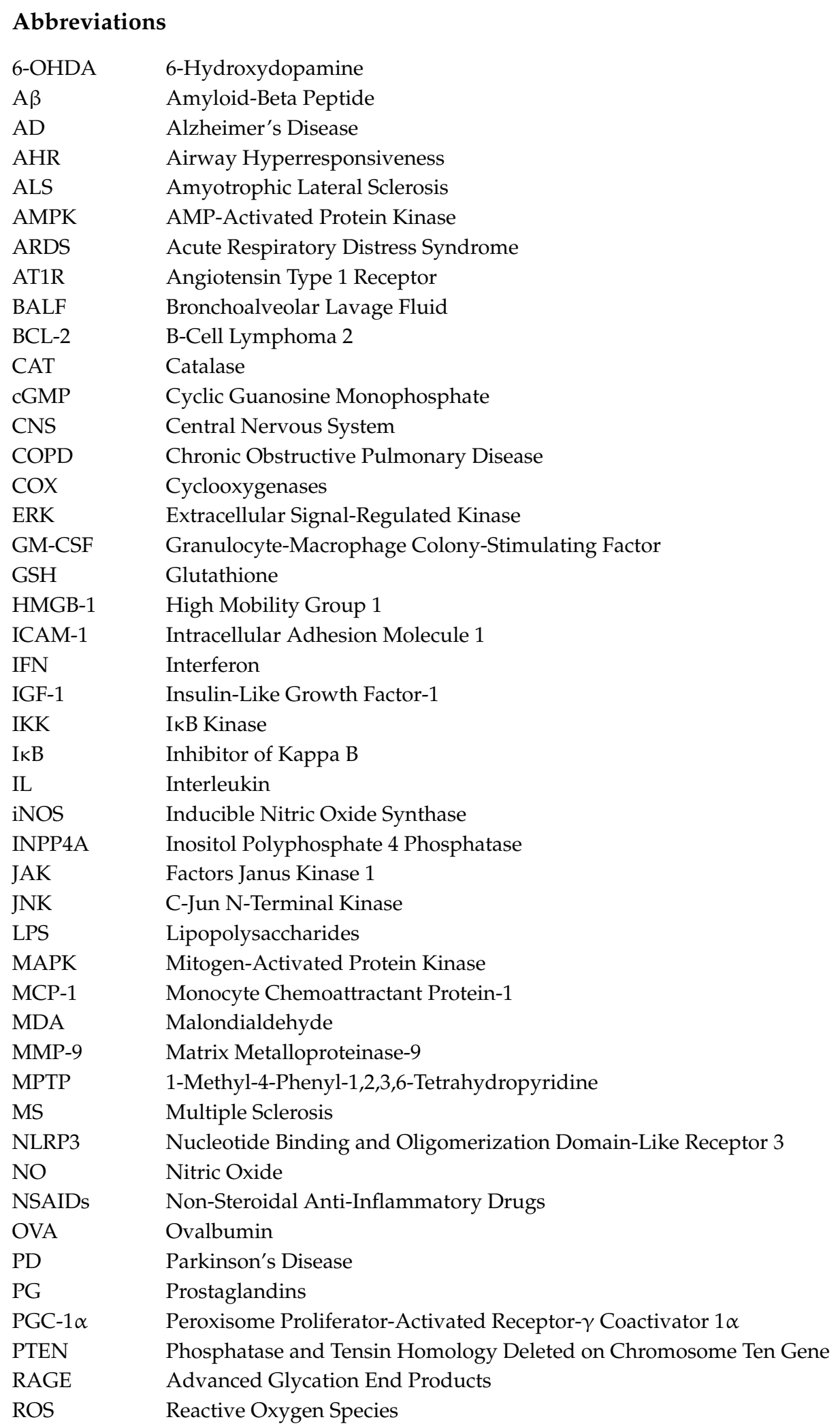




$\begin{array}{ll}\text { RSV } & \text { Resveratrol } \\ \text { SIRT-1 } & \text { Sirtuin 1 } \\ \text { SOD } & \text { Superoxide Dismutase } \\ \text { STAT } & \text { Signal Transducer and Activator of Transcription } \\ \text { TGF- } \beta & \text { Transforming Growth Factor Beta } \\ \text { TLR4 } & \text { Toll-Like Receptor } 4 \\ \text { TNF- } \alpha & \text { Tumor Necrosis Factor-Ahlpa } \\ \text { uPA } & \text { Urokinase Plasminogen Activator } \\ \text { uPAR } & \text { Urokinase Plasminogen Activator Receptor } \\ \text { VEGF } & \text { Vascular Endothelial Growth Factor }\end{array}$

\section{References}

1. Kunnumakkara, A.B.; Sailo, B.L.; Banik, K.; Harsha, C.; Prasad, S.; Gupta, S.C.; Bharti, A.C.; Aggarwal, B.B. Chronic diseases, inflammation, and spices: How are they linked? J. Transl. Med. 2018, 16, 14. [CrossRef] [PubMed]

2. Munn, L. Cancer and Inflammation. Wiley Interdiscip. Rev. Syst. Biol. Med. 2017, 9, e1370. [CrossRef] [PubMed]

3. Van Linthout, S.; Tschöpe, C. Inflammation-Cause or Consequence of Heart Failure or Both? Curr. Heart Fail. Rep. 2017, 14, 251-265. [CrossRef] [PubMed]

4. Chen, L.; Deng, H.; Cui, H.; Fang, J.; Zuo, Z.; Deng, J.; Li, Y.; Wang, X.; Zhao, L. Inflammatory responses and inflammation-associated diseases in organs. Oncotarget 2018, 9, 7204-7218. [CrossRef] [PubMed]

5. Serhan, C.N. Treating inflammation and infection in the 21st century: New hints from decoding resolution mediators and mechanisms. FASEB J. 2017, 31, 1273-1288. [CrossRef] [PubMed]

6. Robb, C.T.; Regan, K.H.; Dorward, D.A.; Rossi, A.G. Key mechanisms governing resolution of lung inflammation. Semin. Immunopathol. 2016, 38, 425-448. [CrossRef] [PubMed]

7. Slavich, G.M.; Irwin, M.R. From stress to inflammation and major depressive disorder: A social signal transduction theory of depression. Psychol. Bull. 2014, 140, 774-815. [CrossRef] [PubMed]

8. Pelaia, G.; Vatrella, A.; Busceti, M.T.; Gallelli, L.; Calabrese, C.; Terracciano, R.; Maselli, R. Cellular Mechanisms Underlying Eosinophilic and Neutrophilic Airway Inflammation in Asthma. Mediat. Inflamm. 2015, 2015, 879783. [CrossRef] [PubMed]

9. Esser, N.; Legrand-Poels, S.; Piette, J.; Scheen, A.J.; Paquot, N. Inflammation as a link between obesity, metabolic syndrome and type 2 diabetes. Diabetes Res. Clin. Pract. 2014, 105, 141-150. [CrossRef] [PubMed]

10. Heneka, M.T.; Carson, M.J.; Khoury, J.E.; Landreth, G.E.; Brosseron, F.; Feinstein, D.L.; Jacobs, A.H.; Wyss-Coray, T.; Vitorica, J.; Ransohoff, R.M.; et al. Neuroinflammation in Alzheimer's disease. Lancet Neurol. 2015, 14, 388-405. [CrossRef]

11. Siti, H.N.; Kamisah, Y.; Kamsiah, J. The role of oxidative stress, antioxidants and vascular inflammation in cardiovascular disease (a review). Vasc. Pharmacol. 2015, 71, 40-56. [CrossRef] [PubMed]

12. Nakamura, K.; Smyth, M.J. Targeting cancer-related inflammation in the era of immunotherapy. Immunol. Cell Biol. 2017, 95, 325-332. [CrossRef] [PubMed]

13. Badri, W.; Miladi, K.; Nazari, Q.A.; Greige-Gerges, H.; Fessi, H.; Elaissari, A. Encapsulation of NSAIDs for inflammation management: Overview, progress, challenges and prospects. Int. J. Pharm. 2016, 515, 757-773. [CrossRef] [PubMed]

14. Barnes, P.J. Glucocorticoids. Chem. Immunol. Allergy 2014, 100, 311-316. [PubMed]

15. Oray, M.; Abu Samra, K.; Ebrahimiadib, N.; Meese, H.; Foster, C.S. Long-term side effects of glucocorticoids. Expert Opin. Drug Saf. 2016, 15, 457-465. [CrossRef] [PubMed]

16. Murugaiyah, V.; Mattson, M.P. Neurohormetic Phytochemicals: An Evolutionary-Bioenergetic Perspective. Neurochem. Int. 2015, 89, 271-280. [CrossRef] [PubMed]

17. Jang, M.; Cai, L.; Udeani, G.O.; Slowing, K.V.; Thomas, C.F.; Beecher, C.W.; Fong, H.H.; Farnsworth, N.R.; Kinghorn, A.D.; Mehta, R.G.; et al. Cancer chemopreventive activity of resveratrol, a natural product derived from grapes. Science 1997, 275, 218-220. [CrossRef] [PubMed]

18. Chedea, V.S.; Vicas, S.I.; Sticozzi, C.; Pessina, F.; Frosini, M.; Maioli, E.; Valacchi, G. Resveratrol: From diet to topical usage. Food Funct. 2017, 8, 3879-3892. [CrossRef] [PubMed] 
19. Takaoka, M. Resveratrol, a new phenolic compound from Veratrum grandiflorum. Nippon Kagaku Kaishi 1939, 60, 1090-1100. [CrossRef]

20. Poulsen, M.M.; Fjeldborg, K.; Ornstrup, M.J.; Kjaer, T.N.; Nohr, M.K.; Pedersen, S.B. Resveratrol and inflammation: Challenges in translating pre-clinical findings to improved patient outcomes. Biochim. Biophys. Acta 2015, 1852, 1124-1136. [CrossRef]

21. Renaud, S.; de Lorgeril, M. Wine, alcohol, platelets, and the French paradox for coronary heart disease. Lancet 1992, 339, 1523-1526. [CrossRef]

22. Kundu, J.K.; Shin, Y.K.; Kim, S.H.; Surh, Y.-J. Resveratrol inhibits phorbol ester-induced expression of COX-2 and activation of NF-кB in mouse skin by blocking IкB kinase activity. Carcinogenesis 2006, 27, 1465-1474. [CrossRef] [PubMed]

23. Farris, P.K. Innovative cosmeceuticals: Sirtuin activators and anti-glycation compounds. Semin. Cutan. Med. Surg. 2011, 30, 163-166. [CrossRef] [PubMed]

24. Lephart, E.D. Resveratrol, $4^{\prime}$ Acetoxy Resveratrol, R-equol, Racemic Equol or S-equol as Cosmeceuticals to Improve Dermal Health. Int. J. Mol. Sci. 2017, 18, 1193. [CrossRef] [PubMed]

25. Carter, L.G.; D'Orazio, J.A.; Pearson, K.J. Resveratrol and cancer: Focus on in vivo evidence. Endocr. Relat. Cancer 2014, 21, R209-R225. [CrossRef] [PubMed]

26. Frazzi, R.; Tigano, M. The multiple mechanisms of cell death triggered by resveratrol in lymphoma and leukemia. Int. J. Mol. Sci. 2014, 15, 4977-4993. [CrossRef] [PubMed]

27. Oyenihi, O.R.; Oyenihi, A.B.; Adeyanju, A.A.; Oguntibeju, O.O. Antidiabetic Effects of Resveratrol: The Way Forward in Its Clinical Utility. J. Diabetes Res. 2016, 2016, 9737483. [CrossRef] [PubMed]

28. Bonnefont-Rousselot, D. Resveratrol and Cardiovascular Diseases. Nutrients 2016, 8, 250. [CrossRef] [PubMed]

29. Howitz, K.T.; Bitterman, K.J.; Cohen, H.Y.; Lamming, D.W.; Lavu, S.; Wood, J.G.; Zipkin, R.E.; Chung, P.; Kisielewski, A.; Zhang, L.L.; et al. Small molecule activators of sirtuins extend Saccharomyces cerevisiae lifespan. Nature 2003, 425, 191-196. [CrossRef] [PubMed]

30. Valenzano, D.R.; Terzibasi, E.; Genade, T.; Cattaneo, A.; Domenici, L.; Cellerino, A. Resveratrol prolongs lifespan and retards the onset of age-related markers in a short-lived vertebrate. Curr. Biol. 2006, 16, 296-300. [CrossRef] [PubMed]

31. Baur, J.A.; Pearson, K.J.; Price, N.L.; Jamieson, H.A.; Lerin, C.; Kalra, A.; Prabhu, V.V.; Allard, J.S.; Lopez-Lluch, G.; Lewis, K.; et al. Resveratrol improves health and survival of mice on a high-calorie diet. Nature 2006, 444, 337-342. [CrossRef] [PubMed]

32. Pirola, L.; Frojdo, S. Resveratrol: One molecule, many targets. IUBMB Life 2008, 60, 323-332. [CrossRef] [PubMed]

33. Rauf, A.; Imran, M.; Suleria, H.A.R.; Ahmad, B.; Peters, D.G.; Mubarak, M.S. A comprehensive review of the health perspectives of resveratrol. Food Funct. 2017, 8, 4284-4305. [CrossRef] [PubMed]

34. Um, J.H.; Park, S.J.; Kang, H.; Yang, S.; Foretz, M.; McBurney, M.W.; Kim, M.K.; Viollet, B.; Chung, J.H. AMP-activated protein kinase-deficient mice are resistant to the metabolic effects of resveratrol. Diabetes 2010, 59, 554-563. [CrossRef] [PubMed]

35. Lagouge, M.; Argmann, C.; Gerhart-Hines, Z.; Meziane, H.; Lerin, C.; Daussin, F.; Messadeq, N.; Milne, J.; Lambert, P.; Elliott, P.; et al. Resveratrol Improves Mitochondrial Function and Protects against Metabolic Disease by Activating SIRT1 and PGC-1 $\alpha$. Cell 2006, 127, 1109-1122. [CrossRef] [PubMed]

36. Shang, J.; Chen, L.L.; Xiao, F.X.; Sun, H.; Ding, H.C.; Xiao, H. Resveratrol improves non-alcoholic fatty liver disease by activating AMP-activated protein kinase. Acta Pharmacol. Sin. 2008, 29, 698-706. [CrossRef] [PubMed]

37. Kim, S.; Jin, Y.; Choi, Y.; Park, T. Resveratrol exerts anti-obesity effects via mechanisms involving down-regulation of adipogenic and inflammatory processes in mice. Biochem. Pharmacol. 2011, 81, 1343-1351. [CrossRef] [PubMed]

38. Tian, Y.; Ma, J.; Wang, W.; Zhang, L.; Xu, J.; Wang, K.; Li, D. Resveratrol supplement inhibited the NF-кB inflammation pathway through activating AMPK $\alpha$-SIRT1 pathway in mice with fatty liver. Mol. Cell. Biochem. 2016, 422, 75-84. [CrossRef] [PubMed]

39. Huang, F.C.; Kuo, H.C.; Huang, Y.H.; Yu, H.R.; Li, S.C. Anti-inflammatory effect of resveratrol in human coronary arterial endothelial cells via induction of autophagy: Implication for the treatment of Kawasaki disease. BMC Pharmacol. Toxicol. 2017, 18, 3. [CrossRef] [PubMed] 
40. Csiszar, A.; Smith, K.; Labinskyy, N.; Orosz, Z.; Rivera, A.; Ungvari, Z. Resveratrol attenuates TNF-alpha-induced activation of coronary arterial endothelial cells: Role of NF-kB inhibition. Am. J. Physiol. Heart Circ. Physiol. 2006, 291, H1694-H1699. [CrossRef] [PubMed]

41. Planavila, A.; Iglesias, R.; Giralt, M.; Villarroya, F. Sirt1 acts in association with PPARalpha to protect the heart from hypertrophy, metabolic dysregulation, and inflammation. Cardiovasc. Res. 2011, 90, $276-284$. [CrossRef] [PubMed]

42. Csiszar, A.; Labinskyy, N.; Podlutsky, A.; Kaminski, P.M.; Wolin, M.S.; Zhang, C.; Mukhopadhyay, P.; Pacher, P.; Hu, F.; de Cabo, R.; et al. Vasoprotective effects of resveratrol and SIRT1: Attenuation of cigarette smoke-induced oxidative stress and proinflammatory phenotypic alterations. Am. J. Physiol. Heart Circ. Physiol. 2008, 294, H2721-H2735. [CrossRef] [PubMed]

43. Riba, A.; Deres, L.; Sumegi, B.; Toth, K.; Szabados, E.; Halmosi, R. Cardioprotective Effect of Resveratrol in a Postinfarction Heart Failure Model. Oxid. Med. Cell. Longev. 2017, 2017, 6819281. [CrossRef] [PubMed]

44. Cong, X.; Li, Y.; Lu, N.; Dai, Y.; Zhang, H.; Zhao, X.; Liu, Y. Resveratrol attenuates the inflammatory reaction induced by ischemia/reperfusion in the rat heart. Mol. Med. Rep. 2014, 9, 2528-2532. [CrossRef] [PubMed]

45. Li, J.; Xie, C.; Zhuang, J.; Li, H.; Yao, Y.; Shao, C.; Wang, H. Resveratrol attenuates inflammation in the rat heart subjected to ischemia-reperfusion: Role of the TLR4/NF-kB signaling pathway. Mol. Med. Rep. 2015, 11, 1120-1126. [CrossRef] [PubMed]

46. Zhang, C.; Lin, G.; Wan, W.; Li, X.; Zeng, B.; Yang, B.; Huang, C. Resveratrol, a polyphenol phytoalexin, protects cardiomyocytes against anoxia/reoxygenation injury via the TLR4/NF-kB signaling pathway. Int. J. Mol. Med. 2012, 29, 557-563. [CrossRef] [PubMed]

47. Yan, F.; Sun, X.; Xu, C. Protective effects of resveratrol improve cardiovascular function in rats with diabetes. Exp. Ther. Med. 2018, 15, 1728-1734. [CrossRef] [PubMed]

48. Gao, Y.; Kang, L.; Li, C.; Wang, X.; Sun, C.; Li, Q.; Liu, R.; Wang, J. Resveratrol Ameliorates Diabetes-Induced Cardiac Dysfunction Through AT1R-ERK/p38 MAPK Signaling Pathway. Cardiovasc. Toxicol. 2016, 16, 130-137. [CrossRef] [PubMed]

49. Dong, W.; Wang, X.; Bi, S.; Pan, Z.; Liu, S.; Yu, H.; Lu, H.; Lin, X.; Ma, T.; Zhang, W. Inhibitory effects of resveratrol on foam cell formation are mediated through monocyte chemotactic protein-1 and lipid metabolism-related proteins. Int. J. Mol. Med. 2014, 33, 1161-1168. [CrossRef] [PubMed]

50. Deng, Z.Y.; Hu, M.M.; Xin, Y.F.; Gang, C. Resveratrol alleviates vascular inflammatory injury by inhibiting inflammasome activation in rats with hypercholesterolemia and vitamin D2 treatment. Inflamm. Res. 2015, 64, 321-332. [CrossRef] [PubMed]

51. Chang, G.-R.; Chen, P.-L.; Hou, P.-H.; Mao, F.C. Resveratrol protects against diet-induced atherosclerosis by reducing low-density lipoprotein cholesterol and inhibiting inflammation in apolipoprotein E-deficient mice. Iran. J. Basic Med. Sci. 2015, 18, 1063-1071. [PubMed]

52. Kode, A.; Rajendrasozhan, S.; Caito, S.; Yang, S.R.; Megson, I.L.; Rahman, I. Resveratrol induces glutathione synthesis by activation of Nrf2 and protects against cigarette smoke-mediated oxidative stress in human lung epithelial cells. Am. J. Physiol. Lung Cell. Mol. Physiol. 2008, 294, L478-L488. [CrossRef] [PubMed]

53. Liu, X.-J.; Bao, H.-R.; Zeng, X.-L.; Wei, J.-M. Effects of resveratrol and genistein on nuclear factor- $\mathrm{kB}$, tumor necrosis factor- $\alpha$ and matrix metalloproteinase- 9 in patients with chronic obstructive pulmonary disease. Mol. Med. Rep. 2016, 13, 4266-4272. [CrossRef] [PubMed]

54. Wang, X.L.; Li, T.; Li, J.H.; Miao, S.Y.; Xiao, X.Z. The Effects of Resveratrol on Inflammation and Oxidative Stress in a Rat Model of Chronic Obstructive Pulmonary Disease. Molecules 2017, 22, 1529. [CrossRef] [PubMed]

55. Liu, H.; Ren, J.; Chen, H.; Huang, Y.; Li, H.; Zhang, Z.; Wang, J. Resveratrol protects against cigarette smoke-induced oxidative damage and pulmonary inflammation. J. Biochem. Mol. Toxicol. 2014, 28, 465-471. [CrossRef] [PubMed]

56. Aich, J.; Mabalirajan, U.; Ahmad, T.; Khanna, K.; Rehman, R.; Agrawal, A.; Ghosh, B. Resveratrol attenuates experimental allergic asthma in mice by restoring inositol polyphosphate 4 phosphatase (INPP4A). Int. Immunopharmacol. 2012, 14, 438-443. [CrossRef] [PubMed]

57. Lee, H.Y.; Kim, I.K.; Yoon, H.K.; Kwon, S.S.; Rhee, C.K.; Lee, S.Y. Inhibitory Effects of Resveratrol on Airway Remodeling by Transforming Growth Factor- $\beta /$ Smad Signaling Pathway in Chronic Asthma Model. Allergy Asthma Immunol. Res. 2017, 9, 25-34. [CrossRef] [PubMed] 
58. Chen, G.; Tang, J.; Ni, Z.; Chen, Q.; Li, Z.; Yang, W.; Din, J.; Luo, X.; Wang, X. Antiasthmatic effects of resveratrol in ovalbumin-induced asthma model mice involved in the upregulation of PTEN. Biol. Pharm. Bull. 2015, 38, 507-513. [CrossRef] [PubMed]

59. Ni, Z.H.; Tang, J.H.; Chen, G.; Lai, Y.M.; Chen, Q.G.; Li, Z.; Yang, W.; Luo, X.M.; Wang, X.B. Resveratrol inhibits mucus overproduction and MUC5AC expression in a murine model of asthma. Mol. Med. Rep. 2016, 13, 287-294. [CrossRef] [PubMed]

60. Jiang, L.; Zhang, L.; Kang, K.; Fei, D.; Gong, R.; Cao, Y.; Pan, S.; Zhao, M. Resveratrol ameliorates LPS-induced acute lung injury via NLRP3 inflammasome modulation. Biomed. Pharmacother. 2016, 84, 130-138. [CrossRef] [PubMed]

61. Qi, Y.; Zhang, G.-J.; Ma, L.-J.; Wang, K.; Wu, J.-Z.; Sun, B.-B.; Hu, X.-G. Effect of Resveratrol on the Expression of p38 Mitogen Activated Protein Kinase and Intercellular Adhesion Molecule-1 in Rats with Lipopolysaccharide-Induced. Acute Lung Inj. 2012, 11, 1831-1836.

62. Capiralla, H.; Vingtdeux, V.; Zhao, H.; Sankowski, R.; Al-Abed, Y.; Davies, P.; Marambaud, P. Resveratrol mitigates lipopolysaccharide- and A $\beta$-mediated microglial inflammation by inhibiting the TLR4/NF-kB/STAT signaling cascade. J. Neurochem. 2012, 120, 461-472. [CrossRef] [PubMed]

63. Yang, X.; Xu, S.; Qian, Y.; Xiao, Q. Resveratrol regulates microglia M1/M2 polarization via PGC-1 $\alpha$ in conditions of neuroinflammatory injury. Brain Behav. Immun. 2017, 64, 162-172. [CrossRef] [PubMed]

64. Mudò, G.; Mäkelä, J.; Liberto, V.D.; Tselykh, T.V.; Olivieri, M.; Piepponen, P.; Eriksson, O.; Mälkiä, A.; Bonomo, A.; Kairisalo, M.; et al. Transgenic expression and activation of PGC-1 $\alpha$ protect dopaminergic neurons in the MPTP mouse model of Parkinson's disease. Cell. Mol. Life Sci. 2012, 69, 1153-1165.

65. Jin, F.; Wu, Q.; Lu, Y.F.; Gong, Q.H.; Shi, J.S. Neuroprotective effect of resveratrol on 6-OHDA-induced Parkinson's disease in rats. Eur. J. Pharmacol. 2008, 600, 78-82. [CrossRef] [PubMed]

66. Frozza, R.L.; Bernardi, A.; Hoppe, J.B.; Meneghetti, A.B.; Battastini, A.M.; Pohlmann, A.R.; Guterres, S.S.; Salbego, C. Lipid-core nanocapsules improve the effects of resveratrol against A $\beta$-induced neuroinflammation. J. Biomed. Nanotechnol. 2013, 9, 2086-2104. [CrossRef] [PubMed]

67. Frozza, R.L.; Bernardi, A.; Hoppe, J.B.; Meneghetti, A.B.; Matté, A.; Battastini, A.M.O.; Pohlmann, A.R.; Guterres, S.S.; Salbego, C. Neuroprotective Effects of Resveratrol Against A $\beta$ Administration in Rats are Improved by Lipid-Core Nanocapsules. Mol. Neurobiol. 2013, 47, 1066-1080. [CrossRef] [PubMed]

68. Yu, H.; Pan, C.; Zhao, S.; Wang, Z.; Zhang, H.; Wu, W. Resveratrol inhibits tumor necrosis factor-alpha-mediated matrix metalloproteinase-9 expression and invasion of human hepatocellular carcinoma cells. Biomed. Pharmacother. 2008, 62, 366-372. [CrossRef] [PubMed]

69. Ryu, J.; Ku, B.M.; Lee, Y.K.; Jeong, J.Y.; Kang, S.; Choi, J.; Yang, Y.; Lee, D.H.; Roh, G.S.; Kim, H.J.; et al. Resveratrol reduces TNF-alpha-induced U373MG human glioma cell invasion through regulating NF- $\mathrm{KB}$ activation and uPA/uPAR expression. Anticancer Res 2011, 31, 4223-4230. [PubMed]

70. Zhang, X.; Jiang, A.; Qi, B.; Ma, Z.; Xiong, Y.; Dou, J.; Wang, J. Resveratrol Protects against Helicobacter pylori-Associated Gastritis by Combating Oxidative Stress. Int. J. Mol. Sci. 2015, 16, 27757-27769. [CrossRef] [PubMed]

71. Tino, A.B.; Chitcholtan, K.; Sykes, P.H.; Garrill, A. Resveratrol and acetyl-resveratrol modulate activity of VEGF and IL-8 in ovarian cancer cell aggregates via attenuation of the NF- $k B$ protein. J. Ovarian Res. 2016, 9, 84. [CrossRef] [PubMed]

72. Ren, Z.; Wang, L.; Cui, J.; Huoc, Z.; Xue, J.; Cui, H.; Mao, Q.; Yang, R. Resveratrol inhibits NF-kB signaling through suppression of p65 and IкB kinase activities. Pharmazie 2013, 68, 689-694. [PubMed]

73. Panaro, M.A.; Carofiglio, V.; Acquafredda, A.; Cavallo, P.; Cianciulli, A. Anti-inflammatory effects of resveratrol occur via inhibition of lipopolysaccharide-induced NF- $\mathrm{BB}$ activation in Caco-2 and SW480 human colon cancer cells. Br. J. Nutr. 2012, 108, 1623-1632. [CrossRef] [PubMed]

74. Vanamala, J.; Reddivari, L.; Radhakrishnan, S.; Tarver, C. Resveratrol suppresses IGF-1 induced human colon cancer cell proliferation and elevates apoptosis via suppression of IGF-1R/Wnt and activation of p53 signaling pathways. BMC Cancer 2010, 10, 238. [CrossRef] [PubMed]

75. Bai, Y.; Mao, Q.Q.; Qin, J.; Zheng, X.Y.; Wang, Y.B.; Yang, K.; Shen, H.F.; Xie, L.P. Resveratrol induces apoptosis and cell cycle arrest of human T24 bladder cancer cells in vitro and inhibits tumor growth in vivo. Cancer Sci. 2010, 101, 488-493. [CrossRef] [PubMed] 
76. Parekh, P.; Motiwale, L.; Naik, N.; Rao, K.V.K. Downregulation of cyclin D1 is associated with decreased levels of p38 MAP kinases, Akt/PKB and Pak1 during chemopreventive effects of resveratrol in liver cancer cells. Exp. Toxicol. Pathol. 2011, 63, 167-173. [CrossRef] [PubMed]

77. Jiao, Y.; Li, H.; Liu, Y.; Guo, A.; Xu, X.; Qu, X.; Wang, S.; Zhao, J.; Li, Y.; Cao, Y. Resveratrol Inhibits the Invasion of Glioblastoma-Initiating Cells via Down-Regulation of the PI3K/Akt/NF- KB Signaling Pathway. Nutrients 2015, 7, 4383-4402. [CrossRef] [PubMed]

78. Sun, C.; Hu, Y.; Liu, X.; Wu, T.; Wang, Y.; He, W.; Wei, W. Resveratrol downregulates the constitutional activation of nuclear factor- $\mathrm{kB}$ in multiple myeloma cells, leading to suppression of proliferation and invasion, arrest of cell cycle, and induction of apoptosis. Cancer Genet. Cytogenet. 2006, 165, 9-19. [CrossRef] [PubMed]

79. Bhardwaj, A.; Sethi, G.; Vadhan-Raj, S.; Bueso-Ramos, C.; Takada, Y.; Gaur, U.; Nair, A.S.; Shishodia, S.; Aggarwal, B.B. Resveratrol inhibits proliferation, induces apoptosis, and overcomes chemoresistance through down-regulation of STAT3 and nuclear factor-kB-regulated antiapoptotic and cell survival gene products in human multiple myeloma cells. Blood 2007, 109, 2293-2302. [CrossRef] [PubMed]

80. Miloso, M.; Bertelli, A.A.; Nicolini, G.; Tredici, G. Resveratrol-induced activation of the mitogen-activated protein kinases, ERK1 and ERK2, in human neuroblastoma SH-SY5Y cells. Neurosci. Lett. 1999, 264, 141-144. [CrossRef]

81. Yu, R.; Hebbar, V.; Kim, D.W.; Mandlekar, S.; Pezzuto, J.M.; Kong, A.N. Resveratrol inhibits phorbol ester and UV-induced activator protein 1 activation by interfering with mitogen-activated protein kinase pathways. Mol. Pharmacol. 2001, 60, 217-224. [CrossRef] [PubMed]

82. Vian, M.A.; Tomao, V.; Gallet, S.; Coulomb, P.O.; Lacombe, J.M. Simple and rapid method for cis- and trans-resveratrol and piceid isomers determination in wine by high-performance liquid chromatography using chromolith columns. J. Chromatogr. A 2005, 1085, 224-229. [CrossRef] [PubMed]

83. Walle, T. Bioavailability of resveratrol. Ann. N. Y. Acad. Sci. 2011, 1215, 9-15. [CrossRef] [PubMed]

84. Walle, T.; Hsieh, F.; DeLegge, M.H.; Oatis, J.E., Jr.; Walle, U.K. High absorption but very low bioavailability of oral resveratrol in humans. Drug Metab. Dispos. 2004, 32, 1377-1382. [CrossRef] [PubMed]

85. Cottart, C.H.; Nivet-Antoine, V.; Laguillier-Morizot, C.; Beaudeux, J.L. Resveratrol bioavailability and toxicity in humans. Mol. Nutr. Food Res. 2010, 54, 7-16. [CrossRef] [PubMed]

86. Rotches-Ribalta, M.; Andres-Lacueva, C.; Estruch, R.; Escribano, E.; Urpi-Sarda, M. Pharmacokinetics of resveratrol metabolic profile in healthy humans after moderate consumption of red wine and grape extract tablets. Pharmacol. Res. 2012, 66, 375-382. [CrossRef] [PubMed]

87. Yu, C.; Shin, Y.G.; Chow, A.; Li, Y.; Kosmeder, J.W.; Lee, Y.S.; Hirschelman, W.H.; Pezzuto, J.M.; Mehta, R.G.; van Breemen, R.B. Human, rat, and mouse metabolism of resveratrol. Pharm. Res. 2002, 19, 1907-1914. [CrossRef] [PubMed]

88. Frozza, R.L.; Bernardi, A.; Paese, K.; Hoppe, J.B.; da Silva, T.; Battastini, A.M.; Pohlmann, A.R.; Guterres, S.S.; Salbego, C. Characterization of trans-resveratrol-loaded lipid-core nanocapsules and tissue distribution studies in rats. J. Biomed. Nanotechnol. 2010, 6, 694-703. [CrossRef] [PubMed]

89. Narayanan, N.K.; Nargi, D.; Randolph, C.; Narayanan, B.A. Liposome encapsulation of curcumin and in combination reduces prostate cancer incidence in PTEN knockout mice. Int. J. Cancer 2009, 125, 1-8. [CrossRef] [PubMed]

90. Amri, A.; Chaumeil, J.C.; Sfar, S.; Charrueau, C. Administration of resveratrol: What formulation solutions to bioavailability limitations? J. Control. Release 2012, 158, 182-193. [CrossRef] [PubMed]

91. Summerlin, N.; Soo, E.; Thakur, S.; Qu, Z.; Jambhrunkar, S.; Popat, A. Resveratrol nanoformulations: Challenges and opportunities. Int. J. Pharm. 2015, 479, 282-290. [CrossRef] [PubMed]

92. Singh, A.; Ahmad, I.; Ahmad, S.; Iqbal, Z.; Ahmad, F.J. A novel monolithic controlled delivery system of resveratrol for enhanced hepatoprotection: Nanoformulation development, pharmacokinetics and pharmacodynamics. Drug Dev. Ind. Pharm. 2016, 42, 1524-1536. [CrossRef] [PubMed]

93. Timmers, S.; Hesselink, M.K.; Schrauwen, P. Therapeutic potential of resveratrol in obesity and type 2 diabetes: New avenues for health benefits? Ann. N. Y. Acad. Sci. 2013, 1290, 83-89. [CrossRef] [PubMed]

94. Reaven, G.M. The metabolic syndrome: Time to get off the merry-go-round? J. Intern. Med. 2011, 269, 127-136. [CrossRef] [PubMed]

95. Hotamisligil, G.S. Inflammation and metabolic disorders. Nature 2006, 444, 860-867. [CrossRef] [PubMed] 
96. Semenkovich, C.F. Insulin resistance and atherosclerosis. J. Clin. Investig. 2006, 116, 1813-1822. [CrossRef] [PubMed]

97. Hotamisligil, G.S. Inflammation, metaflammation and immunometabolic disorders. Nature 2017, 542, 177-185. [CrossRef] [PubMed]

98. Kaur, J. A comprehensive review on metabolic syndrome. Cardiol. Res. Pract. 2014, 2014, 943162. [CrossRef] [PubMed]

99. Hubbard, B.P.; Sinclair, D.A. Small molecule SIRT1 activators for the treatment of aging and age-related diseases. Trends Pharmacol. Sci. 2014, 35, 146-154. [CrossRef] [PubMed]

100. Bremer, A.A. Resveratrol Use in Metabolic Syndrome. Metab. Syndr. Relat. Disord. 2014, 12, $493-495$. [CrossRef] [PubMed]

101. Sun, C.; Zhang, F.; Ge, X.; Yan, T.; Chen, X.; Shi, X.; Zhai, Q. SIRT1 improves insulin sensitivity under insulin-resistant conditions by repressing PTP1B. Cell Metab. 2007, 6, 307-319. [CrossRef] [PubMed]

102. Mendez-del Villar, M.; Gonzalez-Ortiz, M.; Martinez-Abundis, E.; Perez-Rubio, K.G.; Lizarraga-Valdez, R. Effect of resveratrol administration on metabolic syndrome, insulin sensitivity, and insulin secretion. Metab. Syndr. Relat. Disord. 2014, 12, 497-501. [CrossRef] [PubMed]

103. Crandall, J.P.; Oram, V.; Trandafirescu, G.; Reid, M.; Kishore, P.; Hawkins, M.; Cohen, H.W.; Barzilai, N. Pilot study of resveratrol in older adults with impaired glucose tolerance. J. Gerontol. A Biol. Sci. Med. Sci. 2012, 67, 1307-1312. [CrossRef] [PubMed]

104. Movahed, A.; Nabipour, I.; Lieben Louis, X.; Thandapilly, S.J.; Yu, L.; Kalantarhormozi, M.; Rekabpour, S.J.; Netticadan, T. Antihyperglycemic effects of short term resveratrol supplementation in type 2 diabetic patients. Evid. Based Complement Altern. Med. 2013, 2013, 851267. [CrossRef] [PubMed]

105. Bhatt, J.K.; Thomas, S.; Nanjan, M.J. Resveratrol supplementation improves glycemic control in type 2 diabetes mellitus. Nutr. Res. 2012, 32, 537-541. [CrossRef] [PubMed]

106. Zhang, C.; Syed, T.W.; Liu, R.; Yu, J. Role of Endoplasmic Reticulum Stress, Autophagy, and Inflammation in Cardiovascular Disease. Front. Cardiovasc. Med. 2017, 4, 29. [CrossRef] [PubMed]

107. Fiatal, S.; Adany, R. Application of Single-Nucleotide Polymorphism-Related Risk Estimates in Identification of Increased Genetic Susceptibility to Cardiovascular Diseases: A Literature Review. Front. Public Health 2017, 5, 358. [CrossRef] [PubMed]

108. Welsh, P.; Grassia, G.; Botha, S.; Sattar, N.; Maffia, P. Targeting inflammation to reduce cardiovascular disease risk: A realistic clinical prospect? Br. J. Pharmacol. 2017, 174, 3898-3913. [CrossRef] [PubMed]

109. Wu, J.M.; Hsieh, T.C.; Yang, C.J.; Olson, S.C. Resveratrol and its metabolites modulate cytokine-mediated induction of eotaxin-1 in human pulmonary artery endothelial cells. Ann. N. Y. Acad. Sci. 2013, 1290, 30-36. [CrossRef] [PubMed]

110. Kaur, G.; Roberti, M.; Raul, F.; Pendurthi, U.R. Suppression of human monocyte tissue factor induction by red wine phenolics and synthetic derivatives of resveratrol. Thromb. Res. 2007, 119, 247-256. [CrossRef] [PubMed]

111. Gu, X.S.; Wang, Z.B.; Ye, Z.; Lei, J.P.; Li, L.; Su, D.F.; Zheng, X. Resveratrol, an activator of SIRT1, upregulates AMPK and improves cardiac function in heart failure. Genet. Mol. Res. 2014, 13, 323-335. [CrossRef] [PubMed]

112. Gupta, P.K.; DiPette, D.J.; Supowit, S.C. Protective effect of resveratrol against pressure overload-induced heart failure. Food Sci. Nutr. 2014, 2, 218-229. [CrossRef] [PubMed]

113. Chun, N.; Haddadin, A.S.; Liu, J.; Hou, Y.; Wong, K.A.; Lee, D.; Rushbrook, J.I.; Gulaya, K.; Hines, R.; Hollis, T.; et al. Activation of complement factor B contributes to murine and human myocardial ischemia/reperfusion injury. PLoS ONE 2017, 12, e0179450. [CrossRef] [PubMed]

114. Thandapilly, S.J.; Louis, X.L.; Behbahani, J.; Movahed, A.; Yu, L.; Fandrich, R.; Zhang, S.; Kardami, E.; Anderson, H.D.; Netticadan, T. Reduced hemodynamic load aids low-dose resveratrol in reversing cardiovascular defects in hypertensive rats. Hypertens. Res. 2013, 36, 866-872. [CrossRef] [PubMed]

115. Rosano, G.M.C.; Vitale, C.; Seferovic, P. Heart Failure in Patients with Diabetes Mellitus. Card. Fail. Rev. 2017, 3, 52-55. [CrossRef]

116. Wu, H.; Sheng, Z.Q.; Xie, J.; Li, R.; Chen, L.; Li, G.N.; Wang, L.; Xu, B. Reduced HMGB 1-Mediated Pathway and Oxidative Stress in Resveratrol-Treated Diabetic Mice: A Possible Mechanism of Cardioprotection of Resveratrol in Diabetes Mellitus. Oxid. Med. Cell. Longev. 2016, 2016, 9836860. [CrossRef] [PubMed] 
117. Delucchi, F.; Berni, R.; Frati, C.; Cavalli, S.; Graiani, G.; Sala, R.; Chaponnier, C.; Gabbiani, G.; Calani, L.; Del Rio, D.; et al. Resveratrol treatment reduces cardiac progenitor cell dysfunction and prevents morpho-functional ventricular remodeling in type-1 diabetic rats. PLoS ONE 2012, 7, e39836. [CrossRef] [PubMed]

118. Chistiakov, D.A.; Grechko, A.V.; Myasoedova, V.A.; Melnichenko, A.A.; Orekhov, A.N. The role of monocytosis and neutrophilia in atherosclerosis. J. Cell. Mol. Med. 2018, 22, 1366-1382. [CrossRef] [PubMed]

119. Mattison, J.A.; Wang, M.; Bernier, M.; Zhang, J.; Park, S.S.; Maudsley, S.; An, S.S.; Santhanam, L.; Martin, B.; Faulkner, S.; et al. Resveratrol prevents high fat/sucrose diet-induced central arterial wall inflammation and stiffening in nonhuman primates. Cell. Metab. 2014, 20, 183-190. [CrossRef] [PubMed]

120. Wood, L.G.; Wark, P.A.; Garg, M.L. Antioxidant and anti-inflammatory effects of resveratrol in airway disease. Antioxid. Redox Signal 2010, 13, 1535-1548. [CrossRef] [PubMed]

121. Athanazio, R. Airway disease: Similarities and differences between asthma, COPD and bronchiectasis. Clinics 2012, 67, 1335-1343. [CrossRef]

122. MacNee, W. Oxidative stress and lung inflammation in airways disease. Eur. J. Pharmacol. 2001, 429, $195-207$. [CrossRef]

123. Culpitt, S.V.; Rogers, D.F.; Fenwick, P.S.; Shah, P.; De Matos, C.; Russell, R.E.; Barnes, P.J.; Donnelly, L.E. Inhibition by red wine extract, resveratrol, of cytokine release by alveolar macrophages in COPD. Thorax 2003, 58, 942-946. [CrossRef] [PubMed]

124. Barnes, P.J.; Burney, P.G.; Silverman, E.K.; Celli, B.R.; Vestbo, J.; Wedzicha, J.A.; Wouters, E.F. Chronic obstructive pulmonary disease. Nat. Rev. Dis. Prim. 2015, 1, 15076. [CrossRef] [PubMed]

125. Knobloch, J.; Sibbing, B.; Jungck, D.; Lin, Y.; Urban, K.; Stoelben, E.; Strauch, J.; Koch, A. Resveratrol impairs the release of steroid-resistant inflammatory cytokines from human airway smooth muscle cells in chronic obstructive pulmonary disease. J. Pharmacol. Exp. Ther. 2010, 335, 788-798. [CrossRef] [PubMed]

126. Knobloch, J.; Hag, H.; Jungck, D.; Urban, K.; Koch, A. Resveratrol impairs the release of steroid-resistant cytokines from bacterial endotoxin-exposed alveolar macrophages in chronic obstructive pulmonary disease. Basic Clin. Pharmacol. Toxicol. 2011, 109, 138-143. [CrossRef] [PubMed]

127. Chen, J.; Yang, X.; Zhang, W.; Peng, D.; Xia, Y.; Lu, Y.; Han, X.; Song, G.; Zhu, J.; Liu, R. Therapeutic Effects of Resveratrol in a Mouse Model of LPS and Cigarette Smoke-Induced COPD. Inflammation 2016, 39, 1949-1959. [CrossRef] [PubMed]

128. McCracken, J.L.; Veeranki, S.P.; Ameredes, B.T.; Calhoun, W.J. Diagnosis and Management of Asthma in Adults: A Review. JAMA 2017, 318, 279-290. [CrossRef] [PubMed]

129. Olin, J.T.; Wechsler, M.E. Asthma: Pathogenesis and novel drugs for treatment. BMJ 2014, 349, g5517. [CrossRef] [PubMed]

130. Lee, M.; Kim, S.; Kwon, O.K.; Oh, S.R.; Lee, H.K.; Ahn, K. Anti-inflammatory and anti-asthmatic effects of resveratrol, a polyphenolic stilbene, in a mouse model of allergic asthma. Int. Immunopharmacol. 2009, 9, 418-424. [CrossRef] [PubMed]

131. Royce, S.G.; Dang, W.; Yuan, G.; Tran, J.; El Osta, A.; Karagiannis, T.C.; Tang, M.L.K. Resveratrol has protective effects against airway remodeling and airway hyperreactivity in a murine model of allergic airways disease. Pathobiol. Aging Age Relat. Dis. 2011, 1, 7134. [CrossRef] [PubMed]

132. Chen, J.; Zhou, H.; Wang, J.; Zhang, B.; Liu, F.; Huang, J.; Li, J.; Lin, J.; Bai, J.; Liu, R. Therapeutic effects of resveratrol in a mouse model of HDM-induced allergic asthma. Int. Immunopharmacol. 2015, 25, 43-48. [CrossRef] [PubMed]

133. Andre, D.M.; Calixto, M.C.; Sollon, C.; Alexandre, E.C.; Leiria, L.O.; Tobar, N.; Anhe, G.F.; Antunes, E. Therapy with resveratrol attenuates obesity-associated allergic airway inflammation in mice. Int. Immunopharmacol. 2016, 38, 298-305. [CrossRef] [PubMed]

134. Alghetaa, H.; Mohammed, A.; Sultan, M.; Busbee, P.; Murphy, A.; Chatterjee, S.; Nagarkatti, M.; Nagarkatti, P. Resveratrol protects mice against SEB-induced acute lung injury and mortality by miR-193a modulation that targets TGF- $\beta$ signalling. J. Cell. Mol. Med. 2018, 22, 2644-2655. [CrossRef] [PubMed]

135. Ware, L.B.; Matthay, M.A. The acute respiratory distress syndrome. N. Engl. J. Med. 2000, 342, $1334-1349$. [CrossRef] [PubMed] 
136. Zhang, H.X.; Duan, G.L.; Wang, C.N.; Zhang, Y.Q.; Zhu, X.Y.; Liu, Y.J. Protective effect of resveratrol against endotoxemia-induced lung injury involves the reduction of oxidative/nitrative stress. Pulm. Pharmacol. Ther. 2014, 27, 150-155. [CrossRef] [PubMed]

137. Li, T.; Zhang, J.; Feng, J.; Li, Q.; Wu, L.; Ye, Q.; Sun, J.; Lin, Y.; Zhang, M.; Huang, R.; et al. Resveratrol reduces acute lung injury in a LPS-induced sepsis mouse model via activation of Sirt1. Mol. Med. Rep. 2013, 7, 1889-1895. [CrossRef] [PubMed]

138. Zhang, Z.; Chen, N.; Liu, J.B.; Wu, J.B.; Zhang, J.; Zhang, Y.; Jiang, X. Protective effect of resveratrol against acute lung injury induced by lipopolysaccharide via inhibiting the myd88-dependent Toll-like receptor 4 signaling pathway. Mol. Med. Rep. 2014, 10, 101-106. [CrossRef] [PubMed]

139. Cao, Q.; Jing, C.; Tang, X.; Yin, Y.; Han, X.; Wu, W. Protective effect of resveratrol on acute lung injury induced by lipopolysaccharide in mice. Anat. Rec. 2011, 294, 527-532. [CrossRef] [PubMed]

140. Li, S.; Zhao, G.; Chen, L.; Ding, Y.; Lian, J.; Hong, G.; Lu, Z. Resveratrol protects mice from paraquat-induced lung injury: The important role of SIRT1 and NRF2 antioxidant pathways. Mol. Med. Rep. 2016, 13, 1833-1838. [CrossRef] [PubMed]

141. Wang, G.; Hu, Z.; Fu, Q.; Song, X.; Cui, Q.; Jia, R.; Zou, Y.; He, C.; Li, L.; Yin, Z. Resveratrol mitigates lipopolysaccharide-mediated acute inflammation in rats by inhibiting the TLR4/NF-kBp65/MAPKs signaling cascade. Sci. Rep. 2017, 7, 45006. [CrossRef] [PubMed]

142. Buckley, C.D.; Gilroy, D.W.; Serhan, C.N.; Stockinger, B.; Tak, P.P. The resolution of inflammation. Nat. Rev. Immunol. 2013, 13, 59-66. [CrossRef] [PubMed]

143. Louveau, A.; Harris, T.H.; Kipnis, J. Revisiting the Mechanisms of CNS Immune Privilege. Trends Immunol. 2015, 36, 569-577. [CrossRef] [PubMed]

144. Schwartz, M.; Deczkowska, A. Neurological Disease as a Failure of Brain-Immune Crosstalk: The Multiple Faces of Neuroinflammation. Trends Immunol. 2016, 37, 668-679. [CrossRef] [PubMed]

145. Kipnis, J.; Gadani, S.; Derecki, N.C. Pro-cognitive properties of T cells. Nat. Rev. Immunol. 2012, 12, 663-669. [CrossRef] [PubMed]

146. Schwartz, M.; Baruch, K. The resolution of neuroinflammation in neurodegeneration: Leukocyte recruitment via the choroid plexus. EMBO J. 2014, 33, 7-22. [CrossRef] [PubMed]

147. Franceschi, C.; Campisi, J. Chronic inflammation (inflammaging) and its potential contribution to age-associated diseases. J. Gerontol. A Biol. Sci. Med. Sci. 2014, 69, S4-S9. [CrossRef] [PubMed]

148. Cunningham, C. Microglia and neurodegeneration: The role of systemic inflammation. Glia 2013, 61, 71-90. [CrossRef] [PubMed]

149. Labzin, L.I.; Heneka, M.T.; Latz, E. Innate Immunity and Neurodegeneration. Annu. Rev. Med. 2018, 69, 437-449. [CrossRef] [PubMed]

150. Lynch, M.A. Age-related neuroinflammatory changes negatively impact on neuronal function. Front. Aging Neurosci. 2010, 1, 6. [CrossRef] [PubMed]

151. Heneka, M.T.; O'Banion, M.K. Inflammatory processes in Alzheimer's disease. J. Neuroimmunol. 2007, 184, 69-91. [CrossRef] [PubMed]

152. Frank-Cannon, T.C.; Alto, L.T.; McAlpine, F.E.; Tansey, M.G. Does neuroinflammation fan the flame in neurodegenerative diseases? Mol. Neurodegener. 2009, 4, 47. [CrossRef] [PubMed]

153. Heppner, F.L.; Ransohoff, R.M.; Becher, B. Immune attack: The role of inflammation in Alzheimer disease. Nat. Rev. Neurosci. 2015, 16, 358-372. [CrossRef] [PubMed]

154. Dendrou, C.A.; Fugger, L.; Friese, M.A. Immunopathology of multiple sclerosis. Nat. Rev. Immunol. 2015, 15, 545. [CrossRef] [PubMed]

155. Ransohoff, R.M. How neuroinflammation contributes to neurodegeneration. Science 2016, 353, $777-783$. [CrossRef] [PubMed]

156. Salter, M.W.; Stevens, B. Microglia emerge as central players in brain disease. Nat. Med. 2017, $23,1018$. [CrossRef] [PubMed]

157. Block, M.L.; Zecca, L.; Hong, J.-S. Microglia-mediated neurotoxicity: Uncovering the molecular mechanisms. Nat. Rev. Neurosci. 2007, 8, 57. [CrossRef] [PubMed]

158. Bi, X.L.; Yang, J.Y.; Dong, Y.X.; Wang, J.M.; Cui, Y.H.; Ikeshima, T.; Zhao, Y.Q.; Wu, C.F. Resveratrol inhibits nitric oxide and TNF-alpha production by lipopolysaccharide-activated microglia. Int. Immunopharmacol. 2005, 5, 185-193. [CrossRef] [PubMed] 
159. Candelario-Jalil, E.; de Oliveira, A.C.; Graf, S.; Bhatia, H.S.; Hull, M.; Munoz, E.; Fiebich, B.L. Resveratrol potently reduces prostaglandin E2 production and free radical formation in lipopolysaccharide-activated primary rat microglia. J. Neuroinflamm. 2007, 4, 25. [CrossRef] [PubMed]

160. Lu, X.; Ma, L.; Ruan, L.; Kong, Y.; Mou, H.; Zhang, Z.; Wang, Z.; Wang, J.M.; Le, Y. Resveratrol differentially modulates inflammatory responses of microglia and astrocytes. J. Neuroinflamm. 2010, 7, 46. [CrossRef] [PubMed]

161. Lorenz, P.; Roychowdhury, S.; Engelmann, M.; Wolf, G.; Horn, T.F. Oxyresveratrol and resveratrol are potent antioxidants and free radical scavengers: Effect on nitrosative and oxidative stress derived from microglial cells. Nitric Oxide 2003, 9, 64-76. [CrossRef] [PubMed]

162. Blanchet, J.; Longpre, F.; Bureau, G.; Morissette, M.; DiPaolo, T.; Bronchti, G.; Martinoli, M.G. Resveratrol, a red wine polyphenol, protects dopaminergic neurons in MPTP-treated mice. Prog. Neuropsychopharmacol. Biol. Psychiatry 2008, 32, 1243-1250. [CrossRef] [PubMed]

163. Wang, M.J.; Huang, H.M.; Hsieh, S.J.; Jeng, K.C.; Kuo, J.S. Resveratrol inhibits interleukin-6 production in cortical mixed glial cells under hypoxia/hypoglycemia followed by reoxygenation. J. Neuroimmunol. 2001, 112, 28-34. [CrossRef]

164. Wang, Q.; Xu, J.; Rottinghaus, G.E.; Simonyi, A.; Lubahn, D.; Sun, G.Y.; Sun, A.Y. Resveratrol protects against global cerebral ischemic injury in gerbils. Brain Res. 2002, 958, 439-447. [CrossRef]

165. Inoue, H.; Jiang, X.F.; Katayama, T.; Osada, S.; Umesono, K.; Namura, S. Brain protection by resveratrol and fenofibrate against stroke requires peroxisome proliferator-activated receptor alpha in mice. Neurosci. Lett. 2003, 352, 203-206. [CrossRef] [PubMed]

166. Bureau, G.; Longpre, F.; Martinoli, M.G. Resveratrol and quercetin, two natural polyphenols, reduce apoptotic neuronal cell death induced by neuroinflammation. J. Neurosci. Res. 2008, 86, 403-410. [CrossRef] [PubMed]

167. Shin, J.A.; Lee, H.; Lim, Y.K.; Koh, Y.; Choi, J.H.; Park, E.M. Therapeutic effects of resveratrol during acute periods following experimental ischemic stroke. J. Neuroimmunol. 2010, 227, 93-100. [CrossRef] [PubMed]

168. Simao, F.; Matte, A.; Pagnussat, A.S.; Netto, C.A.; Salbego, C.G. Resveratrol preconditioning modulates inflammatory response in the rat hippocampus following global cerebral ischemia. Neurochem. Int. 2012, 61, 659-665. [CrossRef] [PubMed]

169. Alcolea, D.; Carmona-Iragui, M.; Suarez-Calvet, M.; Sanchez-Saudinos, M.B.; Sala, I.; Anton-Aguirre, S.; Blesa, R.; Clarimon, J.; Fortea, J.; Lleo, A. Relationship between beta-Secretase, inflammation and core cerebrospinal fluid biomarkers for Alzheimer's disease. J. Alzheimers Dis. 2014, 42, 157-167. [CrossRef] [PubMed]

170. Swardfager, W.; Lanctôt, K.; Rothenburg, L.; Wong, A.; Cappell, J.; Herrmann, N. A Meta-Analysis of Cytokines in Alzheimer's Disease. Biol. Psychiatry 2010, 68, 930-941. [CrossRef] [PubMed]

171. Perry, V.H.; Nicoll, J.A.R.; Holmes, C. Microglia in neurodegenerative disease. Nat. Rev. Neurol. 2010, 6, 193-201. [CrossRef] [PubMed]

172. Hong, S.; Dissing-Olesen, L.; Stevens, B. New insights on the role of microglia in synaptic pruning in health and disease. Curr. Opin. Neurobiol. 2016, 36, 128-134. [CrossRef] [PubMed]

173. Lee, C.Y.; Landreth, G.E. The role of microglia in amyloid clearance from the AD brain. J. Neural Transm. 2010, 117, 949-960. [CrossRef] [PubMed]

174. Wang, W.-Y.; Tan, M.-S.; Yu, J.-T.; Tan, L. Role of pro-inflammatory cytokines released from microglia in Alzheimer's disease. Ann. Transl. Med. 2015, 3, 136. [CrossRef] [PubMed]

175. Calsolaro, V.; Edison, P. Neuroinflammation in Alzheimer's disease: Current evidence and future directions. Alzheimer Dement. J. Alzheimer Assoc. 2016, 12, 719-732. [CrossRef] [PubMed]

176. Wang, J.; Tan, L.; Wang, H.F.; Tan, C.C.; Meng, X.F.; Wang, C.; Tang, S.W.; Yu, J.T. Anti-inflammatory drugs and risk of Alzheimer's disease: An updated systematic review and meta-analysis. J. Alzheimers Dis. 2015, 44, 385-396. [CrossRef] [PubMed]

177. Zhao, H.; Wang, Q.; Cheng, X.; Li, X.; Li, N.; Liu, T.; Li, J.; Yang, Q.; Dong, R.; Zhang, Y.; et al. Inhibitive Effect of Resveratrol on the Inflammation in Cultured Astrocytes and Microglia Induced by A $\beta 1-42$. Neuroscience 2018, 379, 390-404. [CrossRef] [PubMed]

178. Wight, R.D.; Tull, C.A.; Deel, M.W.; Stroope, B.L.; Eubanks, A.G.; Chavis, J.A.; Drew, P.D.; Hensley, L.L. Resveratrol effects on astrocyte function: Relevance to neurodegenerative diseases. Biochem. Biophys. Res. Commun. 2012, 426, 112-115. [CrossRef] [PubMed] 
179. Lourenco, M.V.; Clarke, J.R.; Frozza, R.L.; Bomfim, T.R.; Forny-Germano, L.; Batista, A.F.; Sathler, L.B.; Brito-Moreira, J.; Amaral, O.B.; Silva, C.A.; et al. TNF- $\alpha$ Mediates PKR-Dependent Memory Impairment and Brain IRS-1 Inhibition Induced by Alzheimer's $\beta$-Amyloid Oligomers in Mice and Monkeys. Cell Metabolism 2013, 18, 831-843. [CrossRef] [PubMed]

180. Solberg, N.O.; Chamberlin, R.; Vigil, J.R.; Deck, L.M.; Heidrich, J.E.; Brown, D.C.; Brady, C.I.; Vander Jagt, T.A.; Garwood, M.; Bisoffi, M.; et al. Optical and SPION-Enhanced MR Imaging Shows that trans-Stilbene Inhibitors of NF- $\mathrm{kB}$ Concomitantly Lower Alzheimer's Disease Plaque Formation and Microglial Activation in A $\beta$ PP/PS-1 Transgenic Mouse Brain. J. Alzheimer Dis. JAD 2014, 40, 191-212. [CrossRef] [PubMed]

181. Siegel, R.L.; Miller, K.D.; Jemal, A. Cancer statistics, 2018. CA Cancer J. Clin. 2018, 68, 7-30. [CrossRef] [PubMed]

182. Hong, W.K.; Sporn, M.B. Recent advances in chemoprevention of cancer. Science 1997, 278, $1073-1077$. [CrossRef] [PubMed]

183. Chai, E.Z.; Siveen, K.S.; Shanmugam, M.K.; Arfuso, F.; Sethi, G. Analysis of the intricate relationship between chronic inflammation and cancer. Biochem. J. 2015, 468, 1-15. [CrossRef] [PubMed]

184. Elinav, E.; Nowarski, R.; Thaiss, C.A.; Hu, B.; Jin, C.; Flavell, R.A. Inflammation-induced cancer: Crosstalk between tumours, immune cells and microorganisms. Nat. Rev. Cancer 2013, 13, 759-771. [CrossRef] [PubMed]

185. Hussain, S.P.; Harris, C.C. Inflammation and cancer: An ancient link with novel potentials. Int. J. Cancer 2007, 121, 2373-2380. [CrossRef] [PubMed]

186. Colotta, F.; Allavena, P.; Sica, A.; Garlanda, C.; Mantovani, A. Cancer-related inflammation, the seventh hallmark of cancer: Links to genetic instability. Carcinogenesis 2009, 30, 1073-1081. [CrossRef] [PubMed]

187. Rajagopal, C.; Lankadasari, M.B.; Aranjani, J.M.; Harikumar, K.B. Targeting oncogenic transcription factors by polyphenols: A novel approach for cancer therapy. Pharmacol. Res. 2018, 130, 273-291. [CrossRef] [PubMed]

188. Siddiqui, I.A.; Sanna, V.; Ahmad, N.; Sechi, M.; Mukhtar, H. Resveratrol nanoformulation for cancer prevention and therapy. Ann. N. Y. Acad. Sci. 2015, 1348, 20-31. [CrossRef] [PubMed]

189. Li, Q.; Verma, I.M. NF-kB regulation in the immune system. Nat. Rev. Immunol. 2002, 2, 725-734. [CrossRef] [PubMed]

190. Karin, M. Nuclear factor-kB in cancer development and progression. Nature 2006, 441, 431-436. [CrossRef] [PubMed]

191. Okamoto, T.; Sanda, T.; Asamitsu, K. NF-kB signaling and carcinogenesis. Curr. Pharm. Des. 2007, 13, 447-462. [CrossRef] [PubMed]

192. Zhang, Q.; Lenardo, M.J.; Baltimore, D. 30 Years of NF-kB: A Blossoming of Relevance to Human Pathobiology. Cell 2017, 168, 37-57. [CrossRef] [PubMed]

193. Sethi, G.; Tergaonkar, V. Potential pharmacological control of the NF-kB pathway. Trends Pharmacol. Sci. 2009, 30, 313-321. [CrossRef] [PubMed]

194. Gupta, S.C.; Kim, J.H.; Kannappan, R.; Reuter, S.; Dougherty, P.M.; Aggarwal, B.B. Role of nuclear factor- $\mathrm{kB}$-mediated inflammatory pathways in cancer-related symptoms and their regulation by nutritional agents. Exp. Biol. Med. 2011, 236, 658-671. [CrossRef] [PubMed]

195. Cheng, S.M.; Xing, B.; Li, J.C.; Cheung, B.K.; Lau, A.S. Interferon-gamma regulation of TNF $\alpha$-induced matrix metalloproteinase 3 expression and migration of human glioma T98G cells. Int. J. Cancer 2007, 121, 1190-1196. [CrossRef] [PubMed]

196. Pandurangan, A.K.; Esa, N.M. Dietary non-nutritive factors in targeting of regulatory molecules in colorectal cancer: An update. Asian Pac. J. Cancer Prev. 2013, 14, 5543-5552. [CrossRef] [PubMed]

197. Frazzi, R.; Valli, R.; Tamagnini, I.; Casali, B.; Latruffe, N.; Merli, F. Resveratrol-mediated apoptosis of hodgkin lymphoma cells involves SIRT1 inhibition and FOXO3a hyperacetylation. Int. J. Cancer 2013, 132, 1013-1021. [CrossRef] [PubMed]

198. Osaki, M.; Oshimura, M.; Ito, H. PI3K-Akt pathway: Its functions and alterations in human cancer. Apoptosis 2004, 9, 667-676. [CrossRef] [PubMed]

199. Hawkins, P.T.; Stephens, L.R. PI3K signalling in inflammation. Biochim. Biophys. Acta 2015, 1851, $882-897$. [CrossRef] [PubMed]

200. Bai, D.; Ueno, L.; Vogt, P.K. Akt-mediated regulation of NFkB and the essentialness of NFkB for the oncogenicity of PI3K and Akt. Int. J. Cancer J. Int. Cancer 2009, 125, 2863-2870. [CrossRef] [PubMed] 
201. Park, E.S.; Lim, Y.; Hong, J.T.; Yoo, H.S.; Lee, C.K.; Pyo, M.Y.; Yun, Y.P. Pterostilbene, a natural dimethylated analog of resveratrol, inhibits rat aortic vascular smooth muscle cell proliferation by blocking Akt-dependen pathway. Vasc. Pharmacol. 2010, 53, 61-67. [CrossRef] [PubMed]

202. Meyer, R.; Hatada, E.N.; Hohmann, H.P.; Haiker, M.; Bartsch, C.; Röthlisberger, U.; Lahm, H.W.; Schlaeger, E.J.; van Loon, A.P.; Scheidereit, C. Cloning of the DNA-binding subunit of human nuclear factor $\mathrm{K} \mathrm{B}$ : The level of its mRNA is strongly regulated by phorbol ester or tumor necrosis factor alpha. Proc. Natl. Acad. Sci. USA 1991, 88, 966-970. [CrossRef] [PubMed]

203. Aggarwal, B.B. Nuclear factor-kB: The enemy within. Cancer Cell 2004, 6, 203-208. [CrossRef] [PubMed]

204. Yu, H.; Pardoll, D.; Jove, R. STATs in cancer inflammation and immunity: A leading role for STAT3. Nat. Rev. Cancer 2009, 9, 798-809. [CrossRef] [PubMed]

205. Lassus, P.; Roux, P.; Zugasti, O.; Philips, A.; Fort, P.; Hibner, U. Extinction of rac1 and Cdc42Hs signalling defines a novel p53-dependent apoptotic pathway. Oncogene 2000, 19, 2377-2385. [CrossRef] [PubMed]

206. Lin, H.Y.; Shih, A.; Davis, F.B.; Tang, H.Y.; Martino, L.J.; Bennett, J.A.; Davis, P.J. Resveratrol induced serine phosphorylation of p53 causes apoptosis in a mutant p53 prostate cancer cell line. J. Urol. 2002, 168, 748-755. [CrossRef]

207. Zhang, S.; Cao, H.J.; Davis, F.B.; Tang, H.Y.; Davis, P.J.; Lin, H.Y. Oestrogen inhibits resveratrol-induced post-translational modification of p53 and apoptosis in breast cancer cells. Br. J. Cancer 2004, 91, 178-185. [CrossRef] [PubMed]

208. Bergh, J.J.; Lin, H.Y.; Lansing, L.; Mohamed, S.N.; Davis, F.B.; Mousa, S.; Davis, P.J. Integrin alphaVbeta3 contains a cell surface receptor site for thyroid hormone that is linked to activation of mitogen-activated protein kinase and induction of angiogenesis. Endocrinology 2005, 146, 2864-2871. [CrossRef] [PubMed]

209. Lin, H.Y.; Tang, H.Y.; Keating, T.; Wu, Y.H.; Shih, A.; Hammond, D.; Sun, M.; Hercbergs, A.; Davis, F.B.; Davis, P.J. Resveratrol is pro-apoptotic and thyroid hormone is anti-apoptotic in glioma cells: Both actions are integrin and ERK mediated. Carcinogenesis 2008, 29, 62-69. [CrossRef] [PubMed]

210. Lin, C.; Crawford, D.R.; Lin, S.; Hwang, J.; Sebuyira, A.; Meng, R.; Westfall, J.E.; Tang, H.Y.; Yu, P.Y.; Davis, P.J.; et al. Inducible COX-2-dependent apoptosis in human ovarian cancer cells. Carcinogenesis 2011, 32, 19-26. [CrossRef] [PubMed]

211. Latruffe, N.; Lancon, A.; Frazzi, R.; Aires, V.; Delmas, D.; Michaille, J.J.; Djouadi, F.; Bastin, J.; Cherkaoui-Malki, M. Exploring new ways of regulation by resveratrol involving miRNAs, with emphasis on inflammation. Ann. N. Y. Acad. Sci. 2015, 1348, 97-106. [CrossRef] 